\title{
Coal Technology Program Progress Report for July 1977
}

\section{OAK RIDGE NATIONAL LABORATORY}




\section{DISCLAIMER}

This report was prepared as an account of work sponsored by an agency of the United States Government. Neither the United States Government nor any agency Thereof, nor any of their employees, makes any warranty, express or implied, or assumes any legal liability or responsibility for the accuracy, completeness, or usefulness of any information, apparatus, product, or process disclosed, or represents that its use would not infringe privately owned rights. Reference herein to any specific commercial product, process, or service by trade name, trademark, manufacturer, or otherwise does not necessarily constitute or imply its endorsement, recommendation, or favoring by the United States Government or any agency thereof. The views and opinions of authors expressed herein do not necessarily state or reflect those of the United States Government or any agency thereof. 


\section{DISCLAIMER}

Portions of this document may be illegible in electronic image products. Images are produced from the best available original document. 


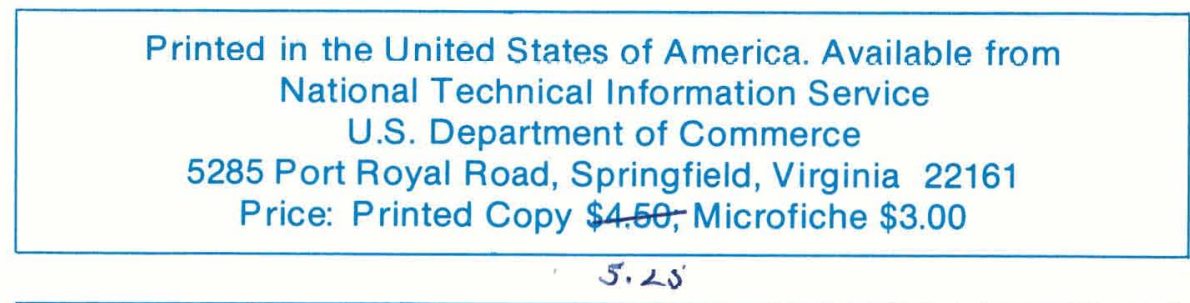

This report was prepared as an account of work sponsored by the United States Government. Neither the United States nor the Energy Research and Development Administration/United States Nuclear Regulatory Commission, nor any of their employees, nor any of their contractors, subcontractors, or their employees, makes any warranty, express or implied, or assumes any legal liability or responsibility for the accuracy, completeness or usefulness of any information, apparatus, product or process disclosed, or represents that its use would not infringe privately owned rights. 
Contract No. W-7405-eng-26

COAL TECHNOLOGY PROGRAM

PROGRESS REPORT FOR JULY 1977

Date Published - August 1977

NOTICE This document contains information of a preliminary nature. It is subject to revision or correction and therefore dnes not represent a final report.

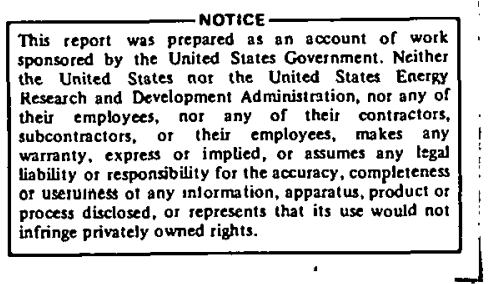

OAK RIDGE NATIONAL LABORATORY

Oak Ridge, Tennessee 37830 operated by

UNION CARBIDE CORPORATION

for the

ENERGY RESEARCH AND DEVELOPMENT ADMINISTRATION 
PREVIOUS REPORTS IN THIS SERIES

ORNL/TM-5044, Progress Report for August 1974

ORNL/TM-5045, Progress Report for September 1974

ORNL/TM-5046, Progress Report for October 1974

ORNL/TM-4787, Progress Report for November 1974.

ORNL/TM-4796, Progress Report for December 1974

ORNL/TM-4850, Progress Report for January 1975

ORNL/TM-4873, Progress Report for February 1975

ORNL/TM-4892, Progress Report for March 1975

ORNL/TM-4946, Progress Report for April 1975

ORNL/TM-4966, Progress Report for May 1975

ORNL/TM-5010, Progress Report for June 1975

ORNL/TM-5037, Progress Report for July 1975

ORNL/TM-5092, Progress Report for August 1975

URINL/TM=5124, Progres3 Report for September 1975

ORNL/TM-5186, Progress Report for October 1975

ORNL/TM-5214, Progress Report for November 1915

ORNL/TM-5246, Progress Report for December 1975.

OR.NL/TM-5301. Progress Report for January 1976

ORNL/TM-5321, Progress Report for February 1976

ORNL/TM-5430, Progress Report for March 1976

ORNL/TM-5479, Progress Report for April 1976

ORNL/TM-5532, Progress Report for May 1976

nRNL/TM-5595, Progress Report for June 1976

ORNL/TM-5611, Progress Report for July 1976

ORNL/TM-5654, Progress Report for August 1976

ORNL/TM-5674, Progress Report for September 1976

ORNL/TM-5717, Progress Report for October 1976

ORNL/TM-5752, Progress Report for November 1976

ORNL/TM-5770, Progress Report for December 1976

ORNL/TM-58.19, Progress Report for January 1977

ORNL/TM-5858, Progress Report for February 1977

ORNL/TM-5883, Progress Report for March 1977

ORNL/TM-5932, Progress Report for April 1.977

ORNL/TM-5980, Progress Report for May 1977

ORNL/TM-6003, Progress Report for June 1977 
CONTENTS

$\underline{\text { Page }}$

Abstract . . . . . . . . . . . . . . . . . . . . 1

1. Summary .. . . . . . . . . . . . . . . . . . 1

2. Coal Conversion Process Development . . . . . . . . . . . . 4

2.1 Hydrocarbonization Research ... . . . . . . . . . . . 4

2.2 Experimental Engineering Support of an
In Situ Gasification Process . . . . . . . . . . . . . 6

2.3 Coal-Solvent-Hydrogen Mixing . . . . . . . . . . . . . 10

2.4 Pressurized Carbonization of Consol Synthetic Fuel Residue • 16

2.5. References for Section 2 . . . . . . . . . . . . . 16

3. Materials Engineering . . . . . . . . . . . . . . . 18

3.1 Pressure Vessel and Piping Materials . . . . . . . . . . . . 19

3.2 Inspection Techniques for Wear- and Process-Resistant
Coatings . . . . . . . . . . . . . . . . . 19

3.3 Development of Techniques for Welding and Cladding. . . . . 20

3.4 Fireside Corrosion . . . . . . . . . . . . . . . . 21

3.5. Failure Analysis . . . . . . . . . . . . . . . . 21

4. Alkali Metal Vapor Topping Cycles . . . . . . . . . . . . 23

4.1 Gas-Fired Potassium Boiler . . . . . . . . . . . . . . 23

4.2 Coal-Fired Alkali Metal Power System . . . . . . . . . . 23

5. Coal Equipment Test Program . . . . . . . . . . . . . 25

6. Fluidized Bed Combustor Technology Test Unit . . . . . . . . . . . 26

6.1 Program Planning . . . . . . . . . . . . . . . 26

6.2 Supplemental Studies . . . . . . . . . . . . . 26

7. Engineering Studies and Technical Support . . . . . . . . . . 28

7.1 Process Modeling . . . . . . . . . . . . . . . . 28

7.2 Synthetic Fuel.s Process Research Digest . . . . . . . . . . 28

7.3 Survey of Industrial Coal Conversion Equipment
Capabilities . . . . . . . . . . . . . . 29

7.4 Engineering Assistance . . . . . . . . . . . . . 32

7.5 Flash Hydropyrolysis . . . . . . . . . . . . . . . 33

7.6 Hot Gas Purification Processes ............. . 33 
Page

7.7 Large Air Separation Plant Study . . . . . . . . . . 33

7.8 Review of State-of-the-Art of Processes for Heat Recovery .. . . . . . . . . . . . . 34

7.9 Assessment of a Moving Bed System for Heat Recovery and Contaminant Removal from Raw Gasifier Gas . . . . . . 35

7.10 Technical/Economic Assessment of Hydrogen Production by the Steam/Molten Iron Process . . . . . . . . . . 37

7.11 A Study of Effluent Control Technologies for Hydrocarbon and Carbon Monoxide Emissions from Coal Conversion Plants - DECT . . . . . . . . . . 37

8. Process and Program Analysis . . . . . . . . . . . . . 38

8.1 Low Btu Coal Gasification . . . . . . . . . . . . 38

8.2 Direct Combustion . . . . . . . . . . . . . 39

8.3 Advanced Power Conversion Systems. . . . . . . . . . 40

8.4 Liquefaction.................. . . 40

8.5 High Btu Gas . . . . . . . . . . . . . . . . . . 41

8.6 In Situ Coal Gasification ............. 41

8.7 Coal Beneficiation.................. 42

8.8 Gas Cleanup Studies . . . . . . . . . . . . . 42

8.9 Coal Prices and Volumes . . . . . . . . . . . . 43

8.10 The Potential of the Synthesis of Chemicals from . . . . . . . 43
Coal as an ERDA Research Program . . . . .

9. Fossil Energy Environmental Project . . . . . . . . . . . . . 44

9.1 Landfill Storage of Coal Conversion Solld Wastes/Information Assessment . . . . . . . . . . 44

9.2 Landfill Storage of Coal Conversion Solid Wastes/Experimental Phase ............... 44

9.3 Environmental Monitoring Handbook . . . . . . . . . . . 44

9.4 Programmatic Assessment/Pipeline Gas . . . . . . . . . . 45

9.5 Programmatlc Assessment/Fuel CaE . . . . . . . . . . 45 
COAL TECHNOLOGY PROGRAM PROGRESS REPORT FOR JULY 1977

ABSTRACT

This report - the thirty-sixll of a series - is a compendium of monthly progress reports for the ORNL research and development programs that are in support of the increased utilization of coal as a source of clean energy. The projects reported this month include those for coal conversion process development, materials engineering, alkali metal vapor topping cycles, a coal equipment test facility, a fluidized bed combustor technology test unit, engineering and support studies, process and program assistance, and environmental assessment studies.

\section{SUMMARY}

J. P. Nichols

Highlights of our progress in July are as follows:

- In hydrocarbonization research we are conducting cold model tests to determine conditions that will enhance mixing in the recirculating fluidized bed reactor and, thus, make it more suitable for the hydrocarbonization of caking coals.

- In our project for pressurized carbonization of Consol Synthetic Fuel residue, we completed five runs that show a desirably low rate of coking of the recycle solvent that is used to slurry the residue.

- Fracture toughness studies to characterize thick steel plates in the size range likely to be required for large coal conversion systems are continuing. The $21 / 4 \mathrm{Cr}-1$. Mn and $254 \mathrm{~mm}$ thick A543 Class 1 plate materials are being tested.

- Our survey of the need for nondestructive testing methods for coatings is nearly complete and some new ideas have been generated from it. Evaluation of one commerclal eddy-current instrument for measuring thickness of nonconductive coatings is nearly complete. We are attempting to optimize some ultrasonic methods with potential for measurement of coating thickness or detection of unbonds and missing coating areas.

- The effects of important welding variables such as current, trave1 speed, and torch oscillation on the depth of penetration and dilution of type $320 \mathrm{Cb}$ stainless steel cladding deposits have been evaluated for deposits made by the submerged-arc process.

- A $1000 \mathrm{hr}$ exposure of heat exchanger tubes to the fluidized bed combustion conditions of a Fluidyne bed was started. Inconel 600 tubing failed by catastrophic sulfidation after a few days. Tubing has been replaced and the bed was restarted with a higher excess oxygen level. 
- Failure analyses are in progress on several components from the Wilsonville Solvent Refined Coal Plant. A field examination of parts of the main dissolver vessel and associated flanges and covers was completed.

- In our gas-fired potassium boiler project, we completed the mafor portion of the potassium piping installation and are well underway in connecting the electrical and instrument wiring between the control room and the system. Initial testing of the system with potassium is scheduled for November 1 .

- In our engineering studies and evaluations project, we continued work on process modeling, the preparatlun of a Synthctic Fuels Research Digest, a survey of industrial coal conversion equipment capabilitles, and studies of flash hydropyrolysis, hot gas purification processes, processes for heat recovery, and hydrogen production by the steam/molten 1ron process.

- In our process and program analysis studies, we continued studies of low-Btu gasification, direct combustion, advanced power conversion systems, liquefaction, high-Btu gasitication, In situ gasification, and coal benefication. These initial scoping studies are due to be complete with the issuance of reports by October 1 .

- In our experimental project to investigate the landfill storage of solid wastes from coal conversion, we completed plans for laboratory leaching tests and will soon begin the preliminary design of field tests.

- In our coal-fired alkal1 metal power system design study, we completed several variations of the cycle arrangement for the selected atmospheric pressure fluidized bed combustor, developed a preferred concept for the furnace, designed the coal feed and ash handling system, and continued work on the alkali metal condenser-steam generator. This study is due to be complete with the issuance of a draft report by October 1 .

- In the coal equipment test program, we are working with a subcontractor (TRW) to identify critical components in proposed demonstration plants and to plan for the testing of these components in existing or new facilities.

- We received authorization to initiate our fluidized bed cumbustor technology test unit (formerly MIUS) project this month. Our first task after funds are received will be to solicit alternative destgns of a $1.3 \mathrm{MW}(\mathrm{Th})$ boiler to heat air in a closed cycle from industrial boiler manufacturers.

- We completed the second revision of our Environmental Monitoring Handbook. This revision includes all four parts, 1.e., introduction, preconstruction, construction, and operation. 
- The first draft of the Programmatic Environmental Assessment for Pipeline Gas Demonstration Plants was completed and submitted to ERDA for review.

- We inftiated an intensive effort to prepare a Programmatic Environmental Assessment for Fuel Gas Demonstration Plants. 
2. COAL CONVERSION PROCESS DEVELOPMENT

H. D. Cochran, Jr.

Coal conversion process development activities are carrled out in the Chemfcal Technology Division. This section discusses hydrocarbonization studies in a 20-atm bench-scale facility, engineering support studies for in situ gasification, studies for identifying and characterlzing alternate reactor concepts for coal hydroliquefaction, and studies of residue carbonization in a pressurized carbonizer.

\subsection{HydrocarbunLzation Research}

R. L. Andrews, J. Beams, C. H. Brown, Jr., L. S. Dickerson, J. B. Gibson, G. E. Oswald, J, C. Roee, P. R. Westmoreland, and E. L. Youngblood

\subsubsection{Experimental Development}

Work Accomplished. Cold model tests indicate that dimensionless gas velocity, the ratio of actual velocity to minlumu fluidization velocity, may be used satisfactorily to evaluate and scale fluidized bed behavior. These tests used char from Run HC-12 in a uniformly fluidized bed (with helium, nitrogen, or argon) and in a recirculating fluidized bed (with helfum or nitrogen). Comparable data from the region of good solids circulation are shöwh 1n Iable 2.1.

An alternative gas distributor has been suggested to assure downcomer fluidization. In order to eliminate gas bypassing from the distributor plate into the draft tube, the distributor plate would be clevated above the draft tube entrance, leaving a gap for solids flow. Modification of the two-dimensional mock-up to test this configuration began during July.

Work Forecast. Evaluation and development of the modified gas distributor will begin during August. Modeling of the rectrculating flutdized bed will continue.

Table 2.1. Comparison of data at fixed dimensionless velocity. ${ }^{a}$

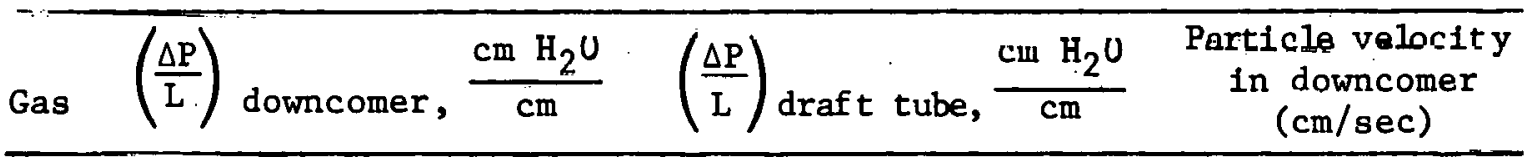

\begin{tabular}{llll}
\hline $\mathrm{He}$ & .421 & .374 & 4 \\
$\mathrm{~N}_{2}$ & .409 & .342 & 3 \\
\hline
\end{tabular}

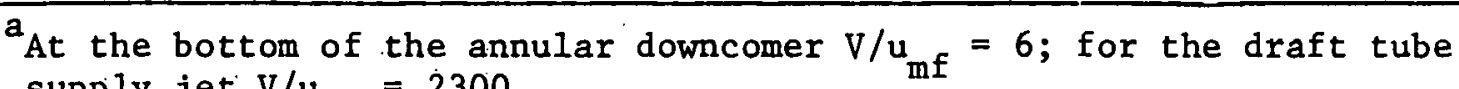
supply. jet $V / u_{m f}=2300$. 


\subsubsection{Bench-Scale Hydrocarbonization}

Work Accomp lished

Fabrication and installation. -- A filtered vent line was installed between the feed hopper and the reactor to enable rapid pressurization and depressurization of the feed hopper during start-up and shut-down operations. The vent line is connected between the feed hopper pressure tap (PT-10) and the reactor tap pressure tap (PT-33). A 2-1n.-schd $40 \times 10$-in.-high filter vessel packed with stainless steel mesh and fiberglas filter media was installed in the line to remove entrained solids. Gas flow rate is controlled by a Research Control valve located in the line.

An activated charcoal trap was installed in the off-gas line directly downstream of the absolute filter in the experiment to enable trapping of any light hydrocarbons which are not condensed or otherwise captured in the water spray scrubber, cold trap and absolute filter. The charcoal trap is constructed of 6 -in. schd 40 carbon steel pipe with a flange at one end. The trap is 14 inches long and will hold approxlmately $3 \mathrm{~kg}$ of activated charcoal.

A coal preheater vessel which is designed to preheat the coal feed to the reactor to about $400^{\circ} \mathrm{F}$ is being fabricated and will be installed in the system in early August.

Operation. -- During July one run, $\mathrm{HC}-21$, was performed using Wyodak subbituminous coal. For this run the draft tube was removed and the reactor was operated in the uniformly fluidized bed mode. The run was performed to prepare char for future runs with char/Illinois No. 6 coal feed and also to measure the oil yield in the uniformly fluldized bed reactor using coal which was prepared under an inert gas blanket. A11 previous runs with a unfformly fluidized bed were made with coal exposed to air during grinding and sieving. A total of $123.3 \mathrm{lb}$ of coal was fed to the reactor in 12.17 hours giving an average coal feed rate of 10.1 $1 \mathrm{~b} / \mathrm{hr}$. The hydrogen feed rate to the system was $12 \mathrm{scfm}$, with 4 scfm to the transport tube, 7 scfm to the distributor plate and 1 scfm to the draft tube nozzle. The steady state bed temperature was $1035^{\circ} \mathrm{F}$. Temperature control and operation of the system during the run was generally good but the coal feed stopped several times, and each time it was necessary to clear the transfer line with gas flow before operation was resumed. The system was operated at 300 psig during the first 5.9 hours of feed, but the pressure was reduced to 267 psig during the last 6.3 hours to allow a higher pressure drop across the transport line in order to overcome some minor fceding difflculties. The difficulties in feeding coal resulted from system pressure fluctuations caused by tar accumulating on the pressure control valve and by a partial restriction in the transport line resulting from a spacer that was moved out of position during assembly. A considerable amount of oil was produced during the run, but quantitative results have not yet been received from chemical analysis. Complete results will be reported next month. 
Presented in Tables 2.2 - 2.4 are detailed analyses of the aqueous scrubber solutions produced in the runs with Wyodak subbituminous coal. (These analyses were made avallable from another development program at ORNL without charge.) Table 2.2 gives the concentration of carbon, phenols, thiocyanate, ammonia, nitrate and phosphate for Runs HC-3 through HC-14. Table 2.3 lists organic compounds which were identified in the scrubber water from Run HC-6. Analyses were performed by gas and liquid chromatography. Table 2.4 presents a detalled characterization of scrubber water from Run HC-4, including the acidity, amount of suspended solids, concentration of phenolic compounds and a detalled trace element analysis.

Work forecast. -- The seals on the scrubber puup will be replaced. The recurrent fallure of these seals is due to char beling forced into the pump overpressure pot during sudden system depressurizations.

Using the liat preparcd during Run HC-21, further tests will be made using mixtures of Illinois No. 6 coal and char. The objective of the next run will be to operate the recirculating fluldized bed with $3 / 1$ char/Illinois No. 6 feed material under conditions that will result in coal being heated to about $1050^{\circ} \mathrm{F}$ before $1 t$ exits the draft tube. In order to achieve a higher temperature in the draft tube, the following modifications will be made:

1. The coal preheater will be installed which w1ll lital the eoal/ $\mathrm{H}_{2}$ feed stream to $400^{\circ} \mathrm{F}$,

2. The draft-tube gas will be preheated to $\sim 1100^{\circ} \mathrm{F}$ (the same temperature as the downcomer supply) and,

3. The transport tube will be thermally insulated from the high temperature draft tube gas by a thin layer of stagnant gas created by inserting the 3/16-in.-diam transport tube through a 3/8-in.-diam tube in the draft tube nozzle. The transport ine is insulated from the hot gas going to the draft tube to prevent particle agglomeration in the transport nozzle.

To enable measurement of the temperature of the stream exiting the draft tube, a thermocouple was inserted $1 / 4$ inch into the draft tube through 2 hole which was drilled through the draft tube well $\sim 2-3 / 8$ inch from the top of the draft tube.

\subsection{Experimental Engineering Support of an In Situ Gasification Process}

J. B. Gibson, L. S. Dickerson, and T. C. Scott

As described in previous reports, samples of Eastern bituminous coal have been obtained from the Morgantown Energy Research Center (MERC) for use in our large-block pyrolysis studies. The coal is typical of the material which will be burned by MERC in their fleld test near Pricetown, West Virginia. 
Table 2.2. Analyses of scrubber water from hydrocarbonization of Wyodak coal

\begin{tabular}{lccccccc}
\hline Run & \multicolumn{5}{c}{ Concentration $\left(\mathrm{ug} / \mathrm{cm}^{3}\right.$ or $\left.\mathrm{g} / \mathrm{m}^{3}\right)$} \\
\cline { 2 - 4 } & $\begin{array}{c}\text { Total organic } \\
\text { carbon }\end{array}$ & $\begin{array}{c}\text { Total } \\
\text { phenols }\end{array}$ & Thiocyanate & Ammonia & Nitrate & Phosphate \\
\hline HC-3 & 9100 & 8100 & 9150 & 427 & 2580 & 7180 & 6 \\
HC-4 & 9100 & 8100 & 11225 & 212 & 5600 & 6470 & 7 \\
HC-5 & 10200 & 8300 & 9850 & 200 & 5800 & 11600 & 2.4 \\
HC-6 & 20000 & 18000 & 10000 & 350 & 6900 & 6475 & 4 \\
HC-8 & 10000 & 8200 & 6000 & 330 & 6600 & 10500 & 5 \\
HC-9 & 3820 & 3200 & 2460 & 400 & 970 & 3750 & 11 \\
HC-10 & 6780 & 5680 & 6550 & 620 & 2900 & 5240 & 5 \\
HC-11 & 4500 & 3800 & 3420 & 330 & 1200 & 3970 & 3.6 \\
HC-12 & 11370 & 10200 & 9725 & 435 & 3040 & 5670 & 2.9 \\
HC-13 & 8800 & 7500 & 8270 & 424 & 5600 & 10080 & 6.5 \\
HC-14 & 7700 & 6200 & 8820 & 820 & 3050 & 6575 & 4.8 \\
\hline
\end{tabular}


Table 2.3. Identifled soluble organic compounds in scrubber water from Run HC- 6

\begin{tabular}{|c|c|c|c|}
\hline \multirow[b]{2}{*}{ Compound } & \multicolumn{3}{|c|}{ Concentration $\left(\mu \mathrm{g} / \mathrm{cm}^{3}\right)$} \\
\hline & By gas & chromatography & $\begin{array}{l}\text { By high-prèssure } \\
\text { liquid chromatography }\end{array}$ \\
\hline $\begin{array}{l}\text { U1merhyl= ul elliyl-substituted } \\
\text { lydruxypyridine }\end{array}$ & & 20 & -- \\
\hline Methy1 carbazole & & 4 & -- \\
\hline Hydroxypyridine & & 10 & -- \\
\hline Methy lhyd roxypyridine & & 10 & -- \\
\hline Catechol & & -- & $\sim 1700$ \\
\hline Hydroquinone & & 4 & 7 \\
\hline Resorcinol & & 29 & 30 \\
\hline Methylresorcinol & & -- & $\sim 2000$ \\
\hline Orcinol & & -- & i2000 \\
\hline Methylcatechol & & 11 & 30 \\
\hline$c_{2}$-substituted dihydroxybenzene & & $<1$ & -- \\
\hline $\mathrm{C}_{3}$-8ubstituted dihydroxybenzene & & $<1$ & $=-$ \\
\hline $\mathrm{C}_{4}$-substicuted diliydroxybenamu & & $<1$ & - \\
\hline
\end{tabular}


Table 2.4. Characterizations of scrubber water from Run HC-4

\begin{tabular}{|c|c|c|}
\hline Acidity & & $\mathrm{pH} 8.82$ \\
\hline $\begin{array}{l}\text { Suspende } \\
(\mu \mathrm{g} / \mathrm{cn}\end{array}$ & solids & 64 \\
\hline $\begin{array}{l}\text { Phenolic } \\
\quad(\mu \mathrm{g} / \mathrm{cn}\end{array}$ & $\begin{array}{l}\text { compounds } \\
\text { 3) }\end{array}$ & \\
\hline $\begin{array}{l}\text { Phe } \\
0-C \\
\text { m- } \\
\text { Cat }\end{array}$ & $\begin{array}{l}\text { col } \\
\text { and p-Cresol } \\
\text { echol }\end{array}$ & $\begin{array}{l}10600 \\
730 \\
2560 \\
290\end{array}$ \\
\hline Trace e] & ements $(\mu \mathrm{g} / \mathrm{cm}$ & \\
\hline $\mathrm{Ag}$ & & $\leq 0.5$ \\
\hline $\mathrm{A} 1$ & & 1.0 \\
\hline As & & $\mathrm{ND}^{\mathrm{a}}$ \\
\hline B & & 0.3 \\
\hline $\mathrm{Ba}$ & & 0.1 \\
\hline $\mathrm{Be}$ & & 0.01 \\
\hline $\mathrm{Ca}$ & & 5. \\
\hline $\mathrm{Cd}$ & & $<0.5$ \\
\hline Co & & $<0.2$ \\
\hline $\mathrm{Cr}$ & & 0.5 \\
\hline $\mathrm{Cn}$ & & 0.1 \\
\hline $\mathrm{Fe}$ & & 1. \\
\hline & . & 3 \\
\hline $\mathrm{L}$ & & $\leq 0.2$ \\
\hline $\mathrm{Mg}$ & & 3 \\
\hline $\mathrm{Mn}$ & & ND \\
\hline Mo & & 0.3 \\
\hline $\mathrm{Na}$ & & 10 \\
\hline $\mathrm{Nb}$ & & 0.3 \\
\hline $\mathrm{Ni}$ & & 3 \\
\hline $\mathrm{P}$ & & 3 \\
\hline $\mathrm{Pb}$ & & ND \\
\hline$S$ & & 20 \\
\hline $\mathrm{Sb}$ & & ND \\
\hline $\mathrm{Se}$ & & ND \\
\hline Si & & 20 \\
\hline $\mathrm{Sn}$ & & ND \\
\hline $\mathrm{Sr}$ & & ND \\
\hline $\mathrm{Ta}$ & & $\mathrm{ND}$ \\
\hline$T_{e}$ & & ND \\
\hline $\mathrm{Ti}$ & & 2 \\
\hline $\mathrm{U}$ & & ND \\
\hline $\mathrm{V}$ & & ND \\
\hline $\mathrm{Zn}$ & & 0.5 \\
\hline
\end{tabular}


During July two experiments were carried out. In Run BP2-31, which completed the experimental matrix with bituminous coal under inert atmosphere, the coal block. was heated at a rate of $0.3 \mathrm{C} / \mathrm{min}$ to $800^{\circ} \mathrm{C}$ and held at $800^{\circ} \mathrm{C}$ unt11 gas evolution ceased. Run BP2-32 was a duplicate of Run BP2-24; it had a heating rate of $3 \mathrm{c} / \mathrm{min}$ and a final temperature of $1000^{\circ} \mathrm{C}$. The duplicate run was performed in order to verify the repeatability of the experiments with bituminous coal.

Analytical results for Runs BP2-29 and BP2-30 were received late in the month. Detailed analysis of these results will be reported in the next monthly.

Conversion of the experimental equipment to allow for hydrogen purge gas is now complete. After final safety commlttee approvel the experiments utilizing hydrogen purge gas' with bituminous coal will begin. The first run in this series should be pes fulimed about mid-nuguet.

\subsection{Coal-Solvent-Hydrogen Mixing}

J. M. Begovich, K. L. Lovelace, alld J. R. Ilightowor, Jr.

Pulse test measurements have continued in the 1-in.-ID $x$ 5-ft-long contactor filled with the Kenics inline static mixers. The contactor was operated with cocurrent upflow of air and water, using flow rates in the range $0-500 \mathrm{~cm} 3 / \mathrm{sec}$ for the a1r and $1-21.5 \mathrm{~cm} 3 / \mathrm{sec}$ for the water. Similar measurements are now under way using the cocurrent upflow of atr and a 35 we \% cual/water slurry through the Kentess sontactor,

Previous experiments using air and water in cocurrent upflow through the 1-In.-ID x 10-ft-long column packed with 4.6-mm-diam glass beads have now been completely analyzed. The results of this analysts are presented in Table 2.5. Water flow rates ranged from $1.92-3.95$ $\mathrm{cm} 3 / \mathrm{sec}$, while air rates were in the range of $0-306 \mathrm{~cm} 3 / \mathrm{sec}$. After Run 115, the glass beads packing was replaced with $1 / 8-1 \mathrm{n} . \times 1 / 8-i n$. alumina extrudates. These porous alumina pellets caused extremely long tails on the residence-time-distribution (RTD) curves and thus yielded erroneously high dispersion coefficienes and liquid holdups. Thus, only the pressure drop and flow rates are reported in Table 2.5 for Runs 116 - 135 .

A comparison of the data for air/water flow through the packed column and air/slurry flow through the column. has not yet been made. However, it should be pointed out that an error was found in the calculation of the energy dissipation per unit volume term as tabulated for the air and coal slurry runs reported previously. 1 The values reported in Table 2.5 have been recalculated correctly, and the air/ coal slurry data will soon be similarly corrected. 
Table 2.5. Preliminary results of dispersion and pressure drop experiments in a packed column with cocurrent upflow of air and water

Column Diameter $=2.54 \mathrm{~cm}$

Column Length $=310 \mathrm{~cm}$

Runs 18 - 115 used 4.6-mm-diam glass beads, bed porosity $=0.42$

Runs 116 - 135 used $1 / 8$-in. $x 1 / 8-i n$.-alumina pellets

\begin{tabular}{|c|c|c|c|c|c|c|c|c|}
\hline $\begin{array}{c}\text { Run } \\
\text { number }\end{array}$ & $\begin{array}{l}\text { Liquid } \\
\text { flow } \\
\mathrm{cm}^{3} / \mathrm{sec}\end{array}$ & $\begin{array}{l}\text { Gas } \\
\text { flow } \\
\mathrm{cm}^{3} / \mathrm{sec}\end{array}$ & $\begin{array}{l}\text { Liquid holdup, } \varepsilon_{L} \\
\quad \text { (fraction of } \\
\text { total bed volume) }\end{array}$ & $\begin{array}{l}\text { Liquid saturation, } \\
R_{L} \text { (fraction of } \\
\text { void volume) }\end{array}$ & $\begin{array}{c}\text { Pressure } \\
\text { drop } \\
\Delta \mathrm{P} \\
\text { psi }\end{array}$ & $\begin{array}{l}\text { Peclet } \\
\text { number } \\
\text { Pe }\end{array}$ & $\begin{array}{l}\text { Dispersion } \\
\text { coefficient, } \\
\mathrm{cm}^{2} / \mathrm{sec}\end{array}$ & $\begin{array}{l}\text { Energy dissipation } \\
\text { per unit volume } \\
\mathrm{v}_{\mathrm{L}} \mathrm{v}_{\mathrm{f}} \\
\mathrm{D}_{\mathrm{ft}} \cdot \mathrm{lb}_{\mathrm{f}} \cdot \mathrm{ft}^{-3} \cdot \mathrm{sec}^{-1}\end{array}$ \\
\hline 18 & 3.95 & 281.2 & 0.133 & 0.317 & 6.00 & 967.8 & 1.88 & 14.7 \\
\hline 19 & 3.95 & 281.2 & 0.136 & 0.324 & 6.00 & 696.6 & 2.56 & 14.3 \\
\hline 20 & 3.95 & 277.1 & 0.130 & 0.310 & 7.40 & 1692 & 1.10 & 19.0 \\
\hline 21 & 3.95 & $2: 7.1$ & 0.130 & 0.310 & 7.40 & 1560 & 1.20 & 18.9 \\
\hline 24 & 3.95 & 285.1 & 0.131 & 0.312 & 7.20 . & 1818 & 1.02 & 18.2 \\
\hline 25 & 3.95 & 285.1 & 0.133 & 0.316 & 7.20 & 985.3 & 1.85 & 17.9 \\
\hline 27 & 3.95 & 25.6 .8 & 0.135 & 0.321 & 5.60 & 2041 & 0.88 & 13.3 \\
\hline 28 & 3.95 & 256.8 & 0.135 & 0.322 & 5.60 & 3860 & 0.46 & 13.3 \\
\hline 31 & 3.95 & 224.4 & 0.137 & 0.325 & 4.40 & 1027 & 1.73 & 9.9 \\
\hline 32. & 3.95 & 224.4 & 0.139 & 0.330 & 4.40 & 1147 & 1.49 & 9.8 \\
\hline 33 & 3.95 & 189.8 & 0.144 & 0.343 & 3.44 & 1266 & 1.33 & 7.0 \\
\hline 34 & 3.95 & 189.8 & 0.145 & 0.345 . & 3.44 & 904.0 & 1.85 & 6.9 \\
\hline 35 & 3.95 & 149.4 & 0.152 & .0 .363 & 2.80 & 636.2 & 2.50 & 5.0 \\
\hline 36 & 3.95 & 149.4 & $0: 153$ & 0.365 & 2.80 & 1053 & 1.50 & 5.0 \\
\hline 37 & 3.95 & 149.4 & 0.154 & 0.366 & 2.80 & 919.9 & 1.71 & 4.9 \\
\hline
\end{tabular}


Table 2.5. (Continued)

\begin{tabular}{|c|c|c|c|c|c|c|c|c|}
\hline $\begin{array}{l}\text { Run } \\
\text { number }\end{array}$ & $\begin{array}{c}\text { Liquid } \\
\text { flow } \\
\mathrm{cm}^{3} / \mathrm{sec}\end{array}$ & $\begin{array}{l}\text { Gas } \\
\mathrm{f} \frac{1}{3} \text { ow } \\
\mathrm{cm}^{3} / \mathrm{sec}\end{array}$ & $\begin{array}{l}\text { E1quid holdup, } \varepsilon_{L} \\
\text { (fraction of } \\
\text { total bed volume) }\end{array}$ & $\begin{array}{l}\text { Liquid sat:iratior, } \\
\mathrm{R}_{\mathrm{I}} \text { (fract:on o: } \\
\text { vold vo-ume) }\end{array}$ & $\begin{array}{c}\text { Pressur } \\
\text { drop } \\
\Delta \mathrm{P} \\
\text { psi }\end{array}$ & $\begin{array}{c}\text { Peclet } \\
\text { number } \\
\text { Pe }\end{array}$ & $\begin{array}{l}\text { Dispersion } \\
\text { coefficient, } \mathrm{D}_{\mathrm{L}} \\
\mathrm{cm}^{2} / \mathrm{sec}\end{array}$ & $\begin{array}{l}\text { Energy dissipation } \\
\text { Per unit volume } \\
\frac{v_{L} \Delta P_{f}}{L} \\
\mathrm{ft} \cdot \mathrm{lb}_{\mathrm{f}} \cdot \mathrm{ft}^{-3} \cdot \mathrm{sec}^{-1}\end{array}$ \\
\hline 39 & 3.95 & 107.4 & 0.174 & 0.41 & 1.60 & 7.62 .7 & 1.83 & 1.7 \\
\hline 40 & 3.95 & 107.4 & 0.173 & 0.411 & 1.60 & 649.6 & 2.17 & 1.7 \\
\hline 43 & 3.95 & 0 & 0.423 & 1.005 & 0.32 & 423.6 & 1.36 & 0 \\
\hline 44 & 3.95 & 0 & 0.423 & 1.003 & 0.32 & 452.7 & 1.27 & 0 \\
\hline 45 & 1.92 & 0 & 0.417 & 0.952 & 0.32 & $\Xi 82.6$ & 0.74 & 0 \\
\hline 46 & 1.92 & 0 & 0.416 & $0.9 G_{1}$ & 0.32 & $\angle 05.3$ & 0.70 & 0 \\
\hline 47 & 3.95 & 187.8 & 0.151 & 0.36 .1 & 4.40 & 1155 & -.39 & 8.9 \\
\hline 48 & 3.95 & 222.2 & 0.147 & $0.3<9$ & $4.4 C$ & 1071 & 1.54 & 9.2 \\
\hline 50 & 2.94 & 284.9 & 0.132 & 0.314 & $6.8 \mathrm{C}$ & 1055 & 1.29 & 12.7 \\
\hline 52 & 2.94 & 292.4 & 0.121 & 0.289 & $6.4 C$ & 280.7 & 5.30 & 13.0 \\
\hline 53 & 2.94 & 292.4 & 0.118 & 0.280 & 6.40 & .54 .2 & 2.03 & 13.3 \\
\hline 54 & 2.94 & 292.4 & $0 . \equiv 17$ & $0.2 \varepsilon 0$ & 6.40 & 549.7 & 2.79 & 13.5 \\
\hline .55 & 2.94 & 292.4 & 0.123 & $0.2 \subseteq 3$ & 6.40 & 595.9 & 2.46 & 12.7 \\
\hline 56 & 2.94 & 292.4 & 0.132 & 0.314 & 6.40 & 536.4 & 2.15 & 11.8 \\
\hline 57 & 2.53 & 292.4 & 0.112 & 0.2 .7 & 6.40 & 358.8 & 1.59 & 12.1 \\
\hline 5.8 & 2.94 & 292.4 & 0.132 & 0.314 & 4.40 & 777.0 & 1.76 & 7.7 \\
\hline 59 & 2.94 & 266.5 & 0.133 & 0.3116 & $4.40^{\circ}$ & 543.6 & 2.50 & 7.7 \\
\hline 60 & 2.94 & 266.5 & 0.134 & $0.3=9$ & 4.40 & 456.8 & 2.95 & 7.6 \\
\hline 61 & 2.94 & 235.9 & 0.142 & 0.339 & 2.810 & 653.0 & 1.94 & 4.1 \\
\hline 62 & 2.94 & 235.9 & 0.141 & 0.3 .35 & 2.8 & 634.5 & 2.02 & 4.1 \\
\hline 63 & 2.94 & 231.4 & 0.135 & 0.320 & $3.2 \mathrm{~J}$ & .488 .4 & 2.74 & 5.1 . \\
\hline 64 & 2.94 & 231.4 & 0.135 & 0.322 & 3.25 & 824.6 & 1.62 & 5.1 \\
\hline
\end{tabular}


Table 2.5: (Continued)

\begin{tabular}{|c|c|c|c|c|c|c|c|c|}
\hline $\begin{array}{l}\text { Run } \\
\text { number }\end{array}$ & $\begin{array}{l}\text { Liquid } \\
\text { flow } \\
\mathrm{cm}^{3} / \mathrm{sec}\end{array}$ & $\begin{array}{l}\text { Gas } \\
\text { flow } \\
\mathrm{cm}^{3} / \mathrm{sec}\end{array}$ & $\begin{array}{l}\text { Liquid holdup, } E_{L} \\
\text { (fraction of } \\
\text { total bed volume) }\end{array}$ & $\begin{array}{l}\text { Liquid saturation, } \\
\mathrm{R}_{\mathrm{L}} \text { (fraction of } \\
\text { void volume) }\end{array}$ & $\begin{array}{c}\text { Pressure } \\
\text { drop } \\
\Delta \mathrm{P} \\
\text { psi }\end{array}$ & $\begin{array}{l}\text { Peclet } \\
\text { number } \\
\text { Pe }\end{array}$ & $\begin{array}{l}\text { Dispersion } \\
\text { coefficient, } \mathrm{R} \\
\mathrm{cm}^{2} / \mathrm{sec}\end{array}$ & $\begin{array}{l}\text { Energy dissipation } \\
\text { per unit volume } \\
\frac{v_{L} \Delta P_{f}}{L} \\
\text { ft } \cdot 1 b_{f} \cdot \mathrm{ft}^{-3} \cdot \mathrm{sec}^{-1}\end{array}$ \\
\hline 65 & 2.94 & $194: 1$ & 0.144 & 0.342 & 2.00 & 1183 & 1.06 & 2.5 \\
\hline 66 & 2.94 & 194.1 & 0.146 & 0.356 & 2.00 & 812.3 & 1.53 & 2.5 \\
\hline 67 & 2.94 & $19<.1$ & 0.146 & 0.348 & 2.00 & 845.5 & 1.46 & 2.5 \\
\hline 68 & 2.94 & 154.7 & 0.159 & 0.379 & 1.20 & 462.8 & 2.45 & 0.8 \\
\hline 69 & 2.94 & 154.7 & 0.159 & 0.379 & 1.20 & 590.0 & 1.92 & 0.8 \\
\hline 73 & 2.94 & 111.3 & 0.131 & 0.432 & 0.80 & 501.3 & 1.98 & 0 \\
\hline 71 & 2.94 & 111.3 & 0.175 & 0.416 & 0.80 & 450.0 & 2.29 & 0 \\
\hline 72 & 2.94 & 111.3 & 0.178 & 0.424 & 0.80 & 395.0 & 2.56 & 0 \\
\hline 73 & 1.92 & 305.6 & 0.116 & 0.277 & 4.80 & 2412 & 0.42 & 6.4 \\
\hline 74 & 1.92 & 305.6 & $0.1 \mathrm{is}$ & 0.274 & 4.80 & 1688 & 0.61 & 6.5 \\
\hline 75 & 1.92 & 274.4 & 0.136 & 0.323 & 3.20 & 1081 & 0.81 & 3.3 \\
\hline 76 & 1.92 & 274.4 & 0.157 & 0.326 & 3.20 & 1235 & 0.70 & 3.3 \\
\hline 77 & 1.92 & 241.0 & 0.142 & 0.338 & 2.00 & 698.2 & 1.19 & 1.7 \\
\hline $7 \varepsilon$ & 1.92 & 241.0 & 0.142 & 0.338 & 2.00 & 647.3 & 1.29 & 1.7 \\
\hline 79 & 1.92 & 241.0 & 0.139 & 0.332 & 2.00 & 1261 & 0.67 & 1.7 \\
\hline 81 & 1.92 & 200.5 & 0.151 & 0.359 & 1.20 & 340.3 & 2.30 & 0.6 \\
\hline 82 & 1.92 & 200.5 & 0.151 & 0.361 & 1.20 & 426.1 & 1.83 & 0.6 \\
\hline 83 & 1.92 & 158.2 & 0.162 & 0.386 & 0.40 & 651.8 & 1.12 & 0 \\
\hline 85 & 1.92 & 158.2 & 0.164 & 0.391 & 0.40 & 540.3 & 1.33 & 0 \\
\hline 86 & 1.92 & 158.2 & 0.165 & 0.392 & 0.40 & 544.6 & 1.32 & 0 \\
\hline 87 & 1.92 & 112.6 & 0.175 & 0.416 & 0.32 & 502.1 & 1.34 & 0 \\
\hline
\end{tabular}


Table 2.5. (Conzinued)

\begin{tabular}{|c|c|c|c|c|c|c|c|c|c|}
\hline $\begin{array}{l}\text { Run } \\
\text { number }\end{array}$ & $\begin{array}{l}\text { Liquid } \\
\text { flow } \\
\mathrm{cm}^{3} / \mathrm{sec}\end{array}$ & $\begin{array}{l}\text { Gas } \\
\text { flow } \\
\mathrm{cm}^{3} / \mathrm{sec}\end{array}$ & $\begin{array}{l}\text { Liquil holdu?, } E_{L} \\
\text { (fraction of } \\
\text { ictal bed volume) }\end{array}$ & $\begin{array}{c}\text { Liquid saturation, } \\
R_{L} \text { ifraction of } \\
\text { void volume) }\end{array}$ & $\begin{array}{c}\text { Pressure } \\
\text { drop } \\
\Delta \mathrm{P} \\
\text { psi }\end{array}$ & $\begin{array}{l}\text { Peclet } \\
\text { number } \\
\text { Pe }\end{array}$ & $\begin{array}{l}\text { Disfersion } \\
\text { coefficient, } \\
\mathrm{cm}^{2} / \mathrm{sec}\end{array}$ & $\mathrm{D}_{\mathrm{L}}$ & $\begin{array}{c}\text { Energy dissipation } \\
\text { per unit volume } \\
\frac{\mathrm{v}_{\mathrm{L}} \Delta \mathrm{P}_{\mathrm{f}}}{\mathrm{L}} \\
\mathrm{ft} \cdot 1 \mathrm{~b}_{\mathrm{f}} \cdot \mathrm{ft}^{-3} \cdot \mathrm{sec}^{-1}\end{array}$ \\
\hline 88 & 1.92 & 112.6 & 0.178 & 0.424 & 0.32 & 442.8 & $i .50$ & - & 0 \\
\hline 89 & 1.92 & 112.6 & 0.191 & 0.454 & 0.32 & 289.7 & 2.14 & & 0 \\
\hline 90 & 1.92 & 112.6 & 0.193 & 0.459 & 0.32 & $2,6.7$ & 2.22 & & 0 \\
\hline 100 & 3.95 & 285.7 & 0.128 & 0.305 & $7.6 C$ & 895.5 & 2.12 & & 19.8 \\
\hline 101 & 3.95 & 255.3 & $0 . \equiv 30$ & 0.369 & 6.80 & 513.7 & 3.64 & & 17.2 \\
\hline 102 & 3.95 & 223.0 & 0.33 & 0.3118 & 4.80 & $6: 8.5$ & 2.94 & & 11.4 \\
\hline 103 & 3.95 & 190.4 & 0.151 & $0.3 \leq 9$ & 3.20 & 827.2 & 1.94 & & 6.0 \\
\hline 104 & 3.95 & 149.9 & 0.161 & 0.38 .2 & 2.40 & 520.1 & 2.91 & & 3.8 \\
\hline 105 & 3.95 & 107.7 & 0.176 & 0.419 & 2.00 & 439.9 & 2.82 & & 2.5 \\
\hline 106 & 3.95 & 284.8 & 0.127 & 0.303 & 7.60 & 607.5 & 3.14 & & 20.0 \\
\hline 107 & 3.95 & 294.3 & 0.138 & 0.328 & 6.40. & 624.9 & 2.82 & & 15.1 \\
\hline 108 & 3.95 & 224.2 & 0.142 & 0.337 & 4.810 & 476.5 & 3.59 & & 10.6 \\
\hline 109 & 3.95 & 187.7 & 0.150 & 0.356 & 3.63 & 434.1 & 3.73 & & 7.0 \\
\hline 110 & 3.95 & 149.3 & 0.157 & 0.373 & 2.83 & 456.5 & 3.39 & & 4.8 \\
\hline 111 & 3.95 & 107.2 & 0.173 & 0.412 & 2.00 & 362.2 & 3.87 & & 2.6 \\
\hline 112 & 2.94 & 294.3 & 0.128 & 0.334 & 6.00 & $\$ 81.3$ & 1.44 & & 11.4 \\
\hline 113 & 2.94 & 294.3 & 0.127 & 0.303 & 6.00 & 10140 & 1.36 & & 11.5 \\
\hline 114 & 2.94 & 263.5 & 0.135 & 0.320 & 4.80 & 642.9 & 2.09 & & 8.4 \\
\hline 115 & 2.94 & 263.5 & 0.134 & 0.320 & 4.80 & 749.6 & 1.79 & & 8.4 \\
\hline 116 & 3.95 & 191.2 & & & 23.28 & & & & . \\
\hline 117 & 3.95 & 196.4 & & & 24.01 & & & & \\
\hline 118 & 3.95 & 196.4 & & & $24 .(11$ & & & & \\
\hline
\end{tabular}


Table 2.5. (Continued)

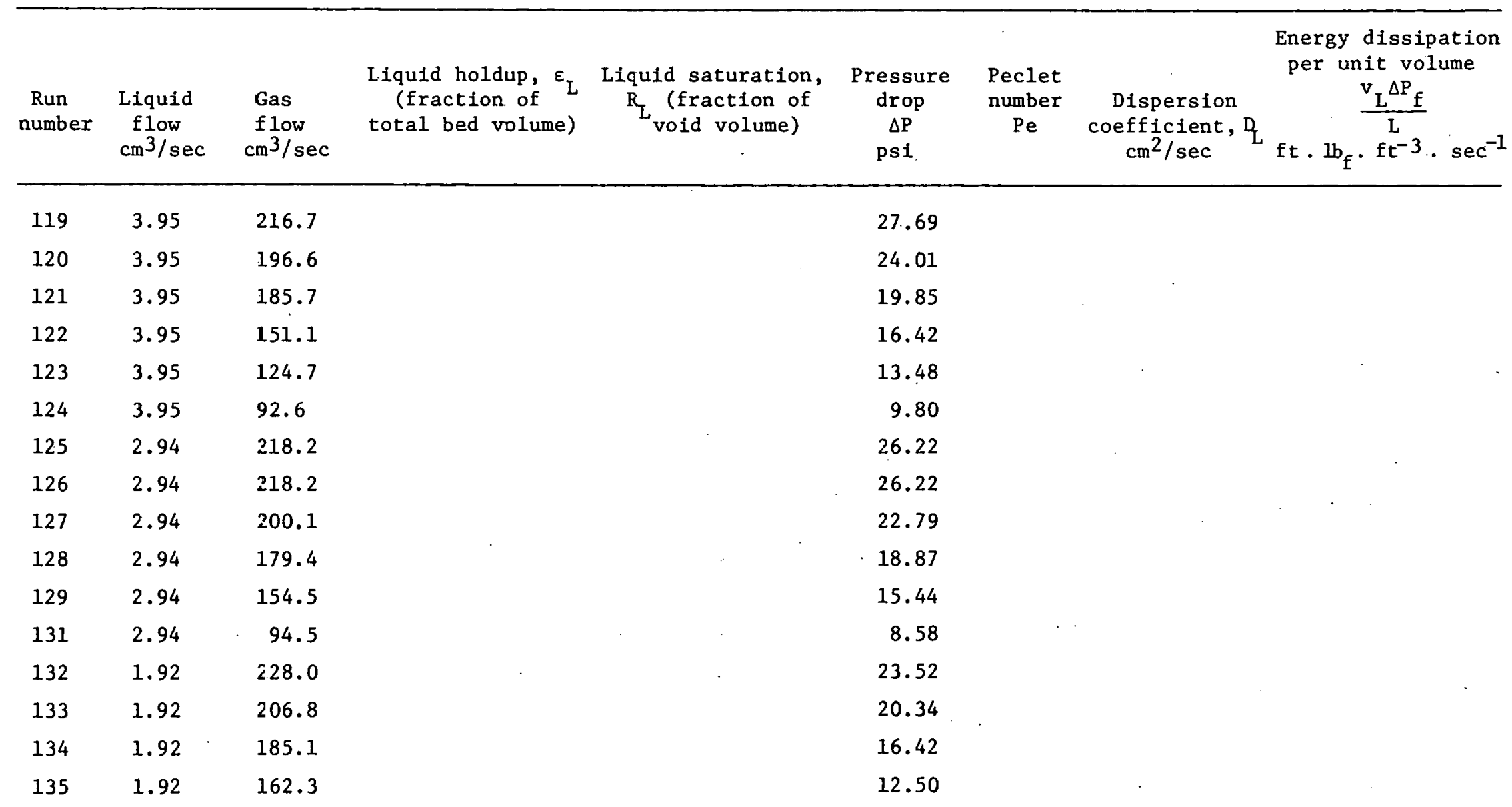




\subsection{Pressurized Carbonization of Consol Synthetic Fuel Residue}

R. E. Barker, S. M. Gibson, and G. D. Smith

This project is intended to determine experimentally the degree of coking and liquid degradation to be expected when Consol Synthetic Fuel (CSF) liquefaction residue is carbonized in a pressurized, fluidized bed carbonizer. The experimental apparatus and results of early experiments are described in earlier reports.

During July five experimental runs were performed. Table 2.6 summarizes the conditions and preliminary coking results of these runs. Note that the coking results are much lower than those reported earlier; however, these runs used an 1mproved spraying technique, which alumb with the new residue which has a lower ash and fixed carbon content, probably caused the lower amount of coking. Also notice that PRC-13 (400 psi) shows a lower amount of coking than Run PRC-14 (50 psi); however, because of some experimental difficulties, results from Run PRC-13 are questionable. PRC-13 w111 be repeated.

All safety approvals for use of hydrogen as the fluidizing gas have been received; the slight modffications required will be made during the next month. Hopefully runs using hydrogen will be made in August.

\section{$2 . \overline{5}$ References for Section 2}

1. J. P. Nichols (ed.), Coal Technology Prugram Frogress Report for June, 1977, ORNL/TM-6003. 
Table 2.6. Preliminary coking results

\begin{tabular}{|c|c|c|c|c|c|c|c|c|}
\hline Run & $\begin{array}{l}\text { Bed } \\
\text { material }\end{array}$ & $\begin{array}{l}\text { Pressure } \\
\text { (psig) }\end{array}$ & $\begin{array}{l}\text { Temperature } \\
\left({ }^{\circ} \mathrm{F}\right)\end{array}$ & $\begin{array}{l}\text { Fluidizing } \\
\text { Gas }\end{array}$ & Feed & $\begin{array}{l}\text { Feed wt } \\
\text { (g) }\end{array}$ & $\begin{array}{l}\text { Coke wt } \\
\text { (g) }\end{array}$ & $\begin{array}{l}\% \text { Feed } \\
\text { coked }\end{array}$ \\
\hline PRC-13 & Alumina & 400.0 & 900.0 & Argon & Residue & 211.0 & 28 . & $13^{c}$ \\
\hline PRC-14 & Alumina & 50.0 & 900.0 & Argon & Residue & 262.0 & 48. & 18. \\
\hline P RC-15 & Alumina & 50.0 & 900.0 & Argon & Solvent ${ }^{a}$ & 271.0 & b & \\
\hline PRC-16 & Alumina & 400.0 & 1050.0 & Argon & Solvent ${ }^{a}$ & \multicolumn{2}{|c|}{$\begin{array}{l}\text { Run was aborted due to } \\
\text { difficulties }\end{array}$} & operating \\
\hline PRC-17 & Char & 50.0 & 900.0 & Argon & Solvent ${ }^{a}$ & 161.0 & b & \\
\hline PRC-18 & Char & 50.0 & 900.0 & Argon & Residue & 346.0 & $b$ & \\
\hline
\end{tabular}

a Solvent is $-700^{\circ} \mathrm{F}$ boiling fraction of residue.

${ }^{b}$ Analytical results for these runs are not complete.

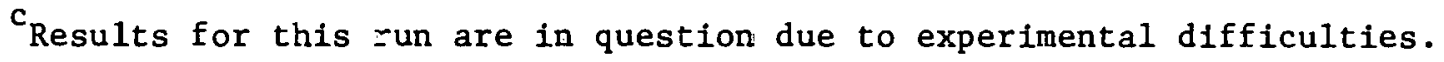




\section{MATERIALS ENGINEERING}

\section{R. T. King}

The materials engineering and associated technology reported here are in support of activities directed by the Materials and Power Generation Branch of the Division of Materials and Exploratory Research, ERDA, in the Division of Fossil Energy. Other related work not funded directly by this division of ERDA/FE is included also.

\section{Summary}

Fracture toughness studies to characterize thick steel plates in the size range likely to be required for large coil conversion systems are continuing. The $21 / 4 \mathrm{Cr}-1 \mathrm{Mo}$ and $254 \mathrm{~mm}$ thick A543 Class 1 plate materials are being tested.

Our survey of the need for nondestructive testing methods for coatings is nearly complete and some new ideas have been generated f'rom it. The general level of effort on this project has been reduced by budget limitations; revised milestone projections have been submitted. Evaluation of one commercial eddy-current instrument for measuring thickness of nonconductive coatings is nearly complete. We are attempting to optimize some ultrasonic methods with potential for measurement of coating thickness or detection of unbonds and missing coating areas.

The effects of important welding variables such as current, travel speed, and torch oscillation on the depth of penetration and dilution of type $320 \mathrm{Cb}$ stainless steel cladding deposits have been evaluated for deposits made by the submerged-arc process.

A $1000 \mathrm{hr}$ exposure of heat exchanger tubes to the fluidized bed combustion conditions of a Fluidyne bed was started. Inconel 600 tubing failed by catastrophic sulfidation after a few days. Tubing has been replaced and the bed was restarted with a higher excess oxvgen level.

Failure analyses are in progress on several components from the Wilsonville Solvent Refined Coal Plant. A field examination of parts of the main dissolver vessel and associated flanges and covers was completed. 


\subsection{Pressure Vessel and Piping Materials}

D. A. Canonico and W. J. Stelzman

This program is aimed at developing fracture toughness data for thick sections of steels that are likely to be used as primary containment for coal conversion processes. There is concern that the properties developed in thick sections may be significantly different from those developed in the thinner sections that compose the bulk of U.S. industrial experience. A device for simulating the thermal cycling that occurs in thick sections, the DATA. TRAK, is being used to provide information at lower cost and more rapidly than can be done by the heat treatment of thick sections.

Characterization of the $254 \mathrm{~mm}$ (10 in.) thick A543 Class I plate is continuing. Currently, we are testing $0.394 \mathrm{~T}$ and $1 \mathrm{~T}$ compact tension specimens. The DATA TRAK simulator is being used with $21 / 4 \mathrm{Cr}-1$ Mo steel to provide additional samples for the fracture toughness evaluation of $2 \mathrm{I} / 4 \mathrm{Cr}-1$ Mo steel.

\subsection{Inspection Techniques for Wear- and Process-Resistant Coatings}

R. W. MeClung and G. W. Scott

\subsubsection{Review and Evaluation (G. W. Scott)}

We need to contact one laboratory to complete our survey of coating applications in the Coal Technology program. There are adequate data to suggest that a major restructuring of the effort merits consideration. As the coating programs continue, there should be excellent opportunities for sharing of specimens with the inspection program.

It has been necessary to reduce the overall level of effort on this project somewhat in order to maintain expenditures within current budget limits. A revised milestone projection has been sent to Dr. W. T. Bakker for insertion in our FY-1977 Work Statement.

\subsubsection{Eddy-Current Testing (G.W. Scott and M. R. Cohen ${ }^{1}$ )}

We have completed evaluation experiments on our Dermitron instrument. The results are being analyzed and assembled into a draft topical report. Although the results obtained will apply directly to one specific instrument, the Dermitron, the experiments are intended to provide quidelines

\footnotetext{
${ }^{1}$ Summer Research Participant, sponsored by Oak Ridge Associated Universities.
} 
and a demonstration of methods for evaluating other bridge-type eddycurrent instruments for applications to lift-off measurements of coating thickness.

\subsubsection{Surface Inspection Materials (S. D. Snyder)}

Cermet tensile crack specimens, No. CP72-COl, with a $0.30 \mathrm{~mm}$ (0.012 in.) thick plasma sprayed coating of $50 \% \mathrm{ZrO}_{2}-50 \% \mathrm{NiCrAl}$ on a IN-800 substrate and No. CPT2T-COI, with a $0.075 \mathrm{~mm}$ ( 0.003 in.) thick NiCrAl bond coat and $0.325 \mathrm{~mm}$ (0.013 in.) thick coating of $50 \% \mathrm{ZrO}_{2}-50 \% \mathrm{NiCrAI}$ on a IN-800 substrate were subjected to a $14.6 \mathrm{kN}$ (3250 lb) tensile load, then bent over a 3.1'23-cm-diam (1 1/4-in.) bar unt11 cracks In lhe cuating became visible at $7 \times$ magnif'ication. Specimen CPT2-COI cracked when its deflection reached about $4 \mathrm{~mm}$ (5/32 in.) and specimen CP72T-COl cracked at a deflection of about $4.7 \mathrm{~mm}$ (3/16 in.). Both specimens sprang back to $3.125 \mathrm{~mm}$ (I/8 in.) dcflection.

Both specimens were radiographed before and after cracking. The aftercracking radiographs showed that a band of cracks about $6.2 \mathrm{~mm}$ ( $1 / 4 \mathrm{in.}$ ) wide developed across the entire throat section of these specimens.

Specimen No. CP72T-COl was used for tests with ZL-IB water washable fluorescent penetrant and our food dye penetrant formulation. Neither of these crack detecting media showed the cracks.

\section{2 .4 UItrasonics (G. W. Scott).}

We have developed mathematical representations and written simple computer programs to aid in optimizing the sensitivity of wedge designs previously reported. ${ }^{2}$ These contact wedge couplers will be tested for ability to measure coating thickness and to detect unbonds ur dreds uf missing coating. The methods were initially developed for flat, parallel surfaces and interfaces. It appears likely that they can be generalized, within certain limits, to surfaces of known curvature and orientation.

We are procuring some lower frequency transducers for our existing pulse-echo thickness gage. The intent is to determine if lower frequency sound can penetrate the plasma-sprayed coating layers to measure thickness.

\subsection{Development of Techniques for Welding and Cladding}

W. C. Oliver and D. P. Edmonds

We are continuing to investigate the influence of welding corditions on the structure and properties of type $320 \mathrm{cb}$ stainless steel clad

\footnotetext{
${ }^{2}$ K. V. Cook, "Ultrasonic Methods," pp. 12-13 in the Coal Technology Program Progress Rejort for March 1977, ORNL/TM-5883.
} 
deposits. During this reporting period we have concentrated on submergedarc (SA) clad deposits on $2.5 \mathrm{~cm}$ thick carbon steel base metal made with varying currents, torch travel speeds, and torch oscillation widths and frequencies. Currents were varied from 450 to $600 \mathrm{~A}$ (AC), travel speeds were varied from 5 to $25 \mathrm{~cm} / \mathrm{min}$, oscillation widths were varied from 0 to $4 \mathrm{~cm}$, and oscillation frequencies of 31 and $53 \mathrm{cycles} / \mathrm{min}$ were used. Maximum depths of penetration varied from $.28 \mathrm{~cm}$ to $.52 \mathrm{~cm}$ and percentage dilution varied from 16 to $45 \%$. For these deposits lower dilutions were obtained with lower welding currents, travel speeds, and lateral torch oscillation speeds (dependent on widths and frequencies). The lower travel speed, with and without torch oscillation, gave the best results.

\subsection{Fireside Corrosion}

R. H. Cooper and J. H. DeVan

During this reporting period the original 12 test heat exchanger tubes from the $500 \mathrm{hr}$ test and six new test specimens were reinserted into the fluidized bed facility at Fluidyne for a subsequent $1000 \mathrm{hr}$ exposure. The $1000 \mathrm{hr}$ exposure was started on July 12 at a bed temperature of $1650^{\circ} \mathrm{F}$ and a flue gas $\mathrm{O}_{2}$ level of $2 \%$. On July 14 the run was temporarily stopped as a result of a failure of one of the Inconel 600 test tubes. Initial analysis of this tube indicates that sulfidation played a major role in this failure. Approximately half of the test specimens in the bed have been replaced and the $1000 \mathrm{hr}$ run will be started again with a reduced bed temperature of $1635^{\circ} \mathrm{F}$ and increased fluidizing velocity which in turn will increase the excess oxygen level to $3 \%$. These operational changes should significantly reduce the potential for future catastrophic sulfidation.

\subsection{Failure Analysis}

\section{R. T. King}

On April 29, 1977 a team from ORNL visited the Solvent Refined Coal Plant at Wilsonville, Alabama. A second plant visit was made on June 14 , 1977. During the tour of the plant, several used components were given to the team for examination. Final failure analysis reports are in preparation for each piece. A summary of the findings is given below.

(1) The inlet orifice for a Worthington centrifugal pump has been found to be a Carpenter 20 type alloy casting.

(2) A pressure letdown valve trim set was supplied. However, since Battelle has performed extensive testing of erosion-corrosion failures in these systems, no failure analysis is planned for this part. 
(3) Two corrosion surveillance coupons exposed to the dissolver tank environment were found to have nonuniform, multiphase scale coatings. Microanalysis of the coating on a type 410 stainless steel specimen revealed a relatively low sulfur content, while analysis of a type 316 stainless steel sample showed a high sulfur content throughout the scale, comparable in magnitude to the major metallic constituents.

(4) A 5-cm-thick (2-in.), 2500 lb-rated type 316 stainless steel blind flange cover with a thermowell from the midpoint of the dissolver was examined. The purpose of the examination was to determine the nature and cause of cracks that had developed in and near to a fillet weld attaching a thermocouple protection tube to the flange. Metallographic examination of the weld area showed the cracks at the weld to be confined to the fusion zone of the weld and not be interconnected with the heat-affected zone. However, a second cràck siystem, unconneoted with the weld cracks, was found on the f'lange. surface surrounding the fillet weld. The appearance of this latter crack system was distinctively that of transgranular stress corrosion cracking. There is a strong argument for attributing the weld cracks to stress corrosion, but their morphology was such that mechanical tearing or pre-existing weld cracks can not be ruled out as a possible cause.

(5) A section of stainless steel filter precoat piping that carries a slurry of solvent and diatomaceous earth suffered an erosion-corrosion failure due to localized attack at geometrical nonuniformities at weld beads.

(6) Springs from the high pressure valve of the hydrogen compressur Pailed in service. Chemical analysis proved the springs to be type 304 stainless steel rather than the intended Alloy X750.

(7) A Dowtherm-jacketed carbon steel line product line that carries liquid coal at $315^{\circ} \mathrm{C}\left(600^{\circ} \mathrm{F}\right)$ was found to be unweldable during a repair operation. Chemical analyses of the materials are in progress.

On Wednesday, July 15, 1977 an inspection and metaliography team from ORNL visited the Solvent Refined Coal Plant at WiLsonville, Alabama, to evaluate the upper internal portions of the maln alssulver lank and the main flange cover that had been made accessible during shutdown. Cracking was found near nuts that had been welded to the inside of the type 347 stainless steel flange cover plate. Cracking was also found on the upper surface of the type 347 stainless steel flange that was welded to the dissolver, but no cracks were tound on the bore of the flange or accessible regions of the cast type 310 stainless steel dissolver tank. 


\title{
4. ALKALI METAL VAPOR TOPPING CYCLES \\ R. S. Holcomb and G. Samuels
}

\subsection{Gas-Fired Potassium Boiler}

\author{
R. S. Holcomb, D. B. Lloyd, and R. H. Guyman
}

\subsubsection{Contract objective}

Design, construction, and testing of a full-scale potassium boiler tube bundle and burner module on water and then potassium to determine the performance and operating characteristics.

\subsubsection{Status summary}

1. Design work was continued on the power supply and controls for the combustion air preheater.

2. The major portion of the potassium piping installation was completed this month. This includes the vapor line between the boiler and condenser and the condensate return line to the boiler. The sample box was set in place and work was begun on connecting piping to it.

3. A11 of the electrical and instrument connecting wiring between the control room and experiment was installed in the conduits. Work was begun on connecting the wiring to the power supplies and instruments in the control room.

\subsubsection{Plans for next month}

Installation of the potassium piping will be completed and helium leak testing of the potassium system will be conducted. Work will continue on connection of electrical and instrument wiring in the control room and begin on wiring connections to inotrument elemtuls and electrical heaters on the experiment.

\subsection{Coa1-Fired Alkali Metal Power System}

G. Samuels

\subsubsection{Contract objective}

The objective of the Coal-Fired Alkali Metal Power System Design Study is to establish a reference design for a 200-MW(e) alkali metal vapor/steam Rankine cycle system employing a coal-fired, atmospheric pressure fluidized bed furnace and to prepare a preliminary design of a fluidized bed furnace. This will be accomplished by studying the relative merits of both potassium and ccsium vapor eycle systems and making a comparison of these systems. 
The results w1ll be analyzed and potassium or ceslum will be chosen as the cycle fluid and one of the systems will be selected as the reference. The reference system w111 be used for the preparation of a preliminary design of a fluldized bed furnace-boiler.

\subsubsection{Status summary}

1. The first phase of the cycle analysis has been completed. This was a parametric analysis of the three basic systems of the plant, i.e., atmospheric, intermediate, and high pressure fluidized bed combustion systems. Several variations of the cycle arrangement for the atmospheric pressure system were analyzed.

2. The first phase of the metal vapor turbine design and analysis has been completed. This effort was restricted to a determination of the number of stages, hub diameter, blade height and stress, and turbine efficiency.

3. The work on the fluidized bed furnace during the first six months of the project was concentrated on a vertical tube boller arrangement for a pressurized furnace and is thus invalidated by the change In direction of the program. The atmospheric furnace concept now being studied is a horizontal forced-circulation unit. The coal feed and ash handling system and the startup procedure for the unit were designed this month.

4. Work on the alkall metal condenser-steatn generacur was cunt:inued. A computer code has been prepared to analyze a reentry tube type unit for this appiication.

\subsubsection{Future work}

Work for the next two months will be concerned with selecting the final design conditions for the reference plant and preparing a draft report describing the plant. Detalls which need to be completed include work on the alkali metal condenser-steam generator, estimating the system inventory, estimating the plant parasitic power losses, sizing the alkall metal turbines, and deriving a general arrangement of the major plant equipment. 
5. COAL EQUIPMENT TEST PROGRAM

R. E. MacPherson

TRW Finergy Systems was active on a subcontract with ORNL during July. The purpose of that work is to develop a plan for utilizing the specialized talents, component test capability, and experience that exists in various national laboratories, energy research centers, private testing laboratories, and industrial facilities.

During the month, R. E. MacPherson and representatives of TRW met with the Illinois Coal Gasification Group (ICGG) to discuss the Coal Equipment Test Program and to seek their cooperation with regard to supplying information about the equipment requirements for their COGAS process. The ICGG was receptive to the idea and there are plans to meet again in the immediate future for further discussions.

A similar meeting with CONOCO is being considered to seek their cooperation in supplying information about the equipment needs for their Slagging Lurgi process. It is recognized that required agreements regarding the access to and handling of proprietary information will have to. be worked out between the participants in these information exchanges. 


\section{FLUIDIZED BED COMBUSTOR TECHNOLOGY TEST UNIT}

R. S. Holcomb

\subsection{Program Planning}

Program planning including review of the schedule and cost was begun this month. No program funds have yet been received and as a result work has not been initiated on the application assessment study or system design. The program schedule will be adjusted to reflect the program tasks beginning at the time the funds are recelved. A new estimate will be made of the construction cost and a new project directive w111 be lequested from ERDAORO.

\subsection{Supplcmental Studies}

The heat transfer test was completed on July 6 . The results will be calcuilated from the test data and an operating report will be prepared by Fluidyne. The data will be analyzed by ORNL and compared to the results of the first test series and to data in the 1iterature.

The corrosion specimens were installed and the corrosion test was begun on July 12. After running for about $46 \mathrm{hr}$, the test was interrupted by a specimen tube rupture on July 14. The furnace was shut down and the failed tube was removed. The tube was weakened at the rupture so much that it broke apart during removal. Visual examination revealed severe corrosion over a length of about $4 \mathrm{in}$. at each end of the tube, which had a composition of Inconel 600 . The remainder of the tubes were subsequently removed and only one other tube appeared to have suffered any significant corrosion attack, an Incoloy 800 tube directiy below the falled tube, and only over a short length near each end with a pitted spot at a point opposite the rupture in the failed tube.

These two tubes were brought to ORNL and samples were cut from the tubes for metallographic examination. Preliminary analysis of the results indicate that "hot corrosion" had occurred of the type that is usually associated with sulfidation attack on nickel alloys. Microprobe scans of the elemental composition of the corrosion product layer revealed the presence of nickel sulfide in the corrosion layer and a depletion of nickel in a zone just below this layer. The pregence of nickel bulfide indicates that at least at the ends of these two tubes, the oxygen level must have been below the value for a stoichiometric air-fuel ratio. Since this type of corrosion did not appear to be present on other tubes in the bed, it is believed that the low oxygen level was a localized condition.

A review of the operating conditions revealed only one factor that may have affected the local oxygen levels that was slgnificantly different in this test from what it was in the first $500 \mathrm{hr}$ test. The transport air in the coal feed line was about $25 \%$ of the total air entering the bed 
whereas before it was only about $12 \%$ of the total air. The increased transport air flow occurred when the leakage air flow across the rotary feeder apparently decreased at the beginning of the test below what it had been during the shakedown run. The air flow to the air distributor plate was set about $14 \%$ lower to maintain the desired overall excess air level. of $10 \%$ as measured in the flue gas exhaust 1 ine.

It is hypothesized that the transport air from the coal feed line did not mix uniformly throughout the bed and this resulted in local areas where reducing conditions existed. This theory is supported by the fact that the two tubes that suffered corrosion attack were located on the side farther away from the coal feed line and near the top of the bed. The absence of attack at the center portion of these tubes indicates that the transport air may have spread everywhere except near the furnace walls on the side away from the coal feed opening. This incident suggests that mixing of air throughout the bed may not be as thorough as coal mixing and that great care may be required to ensure that the air flow rate at every part of the distributor plate is sufficient to provide excess air leaving the bed in each region.

A number of steps have been taken to prepare to resume the corrosion test and to avoid recurrence of the locally severe corrosion conditions. Nine new tubes will replace the six tubes that had no previous exposure and three of the tubes from the first $500 \mathrm{hr}$ test that were nearby the failed tube. The other nine tubes from the 500-hr test will be put back in for further exposure. The overall excess air level will be increased from 10 to $15 \%$ in order to provide a greater margin of safety above reducing conditions. The transport air in the coal feed line will be held to about $12 \%$ of the total air flow. A measurement of the leakage air flow across the rotary feeder and out the vent line will be provided to indicate any change in that flow. Changes that may occur in the leakage will be compensated for by changes in the supply air flow to the coal feed air ejector to maintain the same air flow through the coal feed line, and the air flow through the air distributor will be held constant.

The new tubes have been shipped to FluiDyne and they have installed the thermocouples. It is expected that the furnace will be ready to start up to begin the test about August 10. FluiDyne estimates that the test can still be completed at no increase over the original cost if no further failures occur. 
7. ENGINEERING STUDIES AND TECHINICAL SUPPORT

J. R. McWherter

7.1 Process Modeling

R. Salmon and D. M. Lister

\subsubsection{Contract Objective}

The objective is to assist the Fossil Energy Major Facility Project Management Division of ERDA in its plan for computer analysis and computer support for coal conversion studies. This includes assistance to Purdue and Lehigh Universities in the development of computer programs for this plan.

\section{1 .2 statis sumwarly}

a. Work continued on the computer program for the design and cost estimation of shell-and-tube heat exchangers. A number of example problems were run to compare the cost estimates made by the program.with those given in the literature: An analysis of the results is being made, and the results should be available next month.

b. Manuals and tapes were received from Purdue University describing thoir material halance and physical properties programs. Work is in progress, in collaboration with purdue, to arrange for a series of test runs of physical properties determinations using the Phillips Petroleum PDA program. These will be compared with the results of the Purdue program.

c. Work continued on the installation and testing of the Lehigh DSS-2 program on the ORNL IBM-360-195 computer. Several of the DSS-2 subroutines are being converted to double precision.

\subsubsection{Problem Areas}

Acquisition of process data on the ICGG gasitication syslem remains a problem. The data are needed by purdue and Lehigh in connection with the development of their simulation models, which are to be used on the ICGG f'Lowsheet.

\subsection{Synthetic Fuels Process Research Digest}

$$
\text { F. 'M. S'Hara* }
$$

\subsubsection{Contract Objective}

The objective is to provide continuing technical assistance to the Assistant Director for Processes of the Division of Materials and Exploratory

*Technical Writer working under subcontract. 
Research (DMER) by preparing digest reviews of current or potential subjects relating to coal conversion technology.

\subsubsection{Status Summary}

a. Final mats for review and printing have been prepared for the article about Mobil's conversion of methanol to gasoline and have been circulated for ERDA/FE/DMER approval and internal technical review. Comments on various other articles or sections of articles have been obtained from ERDA/FE/DMER and from contractors whose work is being described. A rewriting of the Brookhaven National Laboratory work on flash hydropyrolysis has been done to update the information in the article to the present level of knowledge. Incorporation of these comments and changes from ERDA and its contractors will allow final mat preparation for two more articles, "Catalytic Coal Gasification" and "Flash Hydropyrolysis of Coal." Comments have still not been received from one contractor or from ERDA/FE/DMER on the article "Zinc Chloride Hydrocracking of Coal and Coal Extracts."

b. Work has begun on writing the articles for the second issue of the Digest. The article on the Consol Synthetic Fuel Process is almost complete, and a purchase order has been written for the production of the Solvent Refined Coal article. Preliminary information has been gathered for the articles on the Fischer-Tropsch Process and on gasification of coal to produce intermediate Btu fuel.

\subsection{Survey of Industrial Coal Conversion Equipment Capabilities}

R. W. Glass and J. M. Holmes

\subsubsection{Contract Objective}

The general objective of this project is to conduct surveys of industrial equipment capabilities that will identify the present capability of industry to supply the equipment needed. The project will also determine research and development needs, including lead time requirements, for producing equipment of advanced design for the various unit operations of critical importance to the Major Facility Project Management Division's (MFPM) programs.

\subsubsection{Rotating Components (J. R. Horton, M. Siman-Tov, and W. R. Williams)}

a. Several sections of the final report have been drafted. A complete rough draft should be ready during the second part of August.

b. A trip was made by B. F. Boudreau, J. R. Horton, and W. R. Williams to discuss compressors and expanders for coal 
conversion plants on July 11,12 , and 13. Companies visited were Ingersoll-Rand (Phillipsburg, $\mathrm{NJ}$, and Allentown, $\mathrm{PA}$ ), Elliott (Jeanette, PA) and Dresser-Clark (Olean, NY). Pumps were also discussed with Ingersoll-Rand.

c. A meeting, with Sulzer Brothers, Inc., a Swiss firm with offices in New York City, was held at ORNL on July 21.

d. A trip to discuss pump and hydraulic turbine capabilities is planned for July 25-29. Companies to be visited are BinghamWilamette (Portland, OR), United ( $S a n$ Jose, CA), Pacific and Byron-Jackson (Los Angeles, CA) and Wilson-Synder (Dallas, TX). Airco Cryogenics, a compressor and expander manufacturer in Irvine, CA, will also be visited on this trip. A trip report will be included in the August monthly report.

e. The availability of slurry pumps, particularly for high pressure applicutions, is at present questionable. Information received to date shows only a few companies indicating the ability to supply such pumps. Equipment life may be a critical consideration affecting conclusions regarding availability.

f. Various expander designs for handling particulate laden streams have been discussed with several companies. Modifications of radial inflow and outflow designs for simultaneous removal of particles and power recovery have been presented as have modifications to the more typical axial design which keep particulates more uniformly distributed in the gas stream, thereby reducing erosion. These modifications are in various stages of development, some being in the design stage and others having actually been applied in service. The extent of particulate loading which can be tolerated by these designs varies widely; however, it is agreed that gas clean-up in advance of the expander is desirable.

g. Compressors for most applications considered in this investigation are available. In some instances multiple units in parallel may be required to handle the flow rates listed. High pressure ratio applications will require several compressors in series since the number of stages required for compression would require excessive shaft lengths in a single unit. The present state-of-the-art for oxygen compressors is around 2200 TPD capacity (approximately 30,000 acfm at inlet conditions). Maximum pressures in $\mathrm{O}_{2}$ compressors of centrifugal design is approximately 700 psia. Higher pressures greatly increase the risk of fire. For higher pressure requirements, reciprocating compressors might be used to boost the pressure from 700 psia. 
7.3.3 Valves and Other Letdown Devices (W. A. Bush and E. C. Slade)

a. Questionnaires were mailed in July to approximately fifty valve actuator manufacturers to enlist their aid in determining manufacturing capabilities and research and development needs for actuators that coula be used with critical valves in coal conversion plants. Critical actuator applications were derived from the preparation portion of this industrial survey in which the critical valves of seven prospective coal conversion processes were determined. In general, critical actuators are located in areas that could be subject to explosive environments. Uncertainties will continue to exist about the torque requirements for these critical locations until experience is gained on the characteristics of the residue that deposits on valve parts and erosion and wear patterns of the specific valve and its specific application have been determined.

b. Responses from the questionnaires sent to ball and blast type valve manufacturers are being analyzed and categorized for inclusion in the final report. The response to date from ball valve manufacturers is approximately $70 \%$. The suggested response date to the questionnaire sent to blast type valve manufacturers is August 15, 1977.

c. Responses to date indicate an interest in the results of this survey. Many manufacturers hope to utilize the survey for longrange production planning and possible R\&D projects, both privately financed and hopefully government financed.

d. A news item about the valve survey was submitted for insertion in the "Valve Manufacturers Association Monthly News Bulletin".

e. The accumulation of catalogs for the critical valve catalog library is continuing.

\subsubsection{Hot Gas Cleanup Devices (J. P. Meyer and M. S. Edwards)}

During the reporting interval, the following work has been completed:

a. A preliminary draft of the final report has been prepared.

b. A symposium on instrumentation and control for fossil demonstration plants held in Chicago July 13-15, 1977, was attended by a task representative. Much of the information presented at this symposium was oriented toward an elucidation of the instrumentation and control problems that will need to be resolved prior to the fabrication of a synthetic fuel demonstration plant. In essence, most of the conference was concerned with the problems associated with building reliable sensing equipment that could withstand the extreme environments encountered in gasifier operation. In distinction, little 
emphasis was given to an exposition on control, that is an understanding of how the underlying dynamics of the system will affect its controllability. In regard to the latter point, it was pointed out by B.G. Liptak of Liptak and Bellyky Associates that a unique problem in low-Btu gasification processes will be the need to match production with load. Given the inherently long time constants associated with many gasification processes, this could be a formidable problem.

7.3.5 Heat Recovery Equipment Survey (W. R. Gambill and W. R. Reed)

a. A tentative outline of the final report for this survey was completed and transmitted to ERDA/FE/MFPM project management.

b. Additional vendor contacts were made. It was learned, e.g., that the heat transfer department of Westinghouse Electric Corp. has fabricated a $7-1$ th-diam. tube sheet $25-1 / 2$ in. thick for a feedwater heater with an internal design pressure of 5000 psi.

c. W. R. Reed of the Engineering Division will aid in this survey work during the next two months. A questionnaire letter and a tabulation of thermal performance criteria for 12 heat exchangers has been prepared and will be sent to 10-12 fabricators of severe-service exchangers for their responses.

d. A categorization of information contained in vendor literature received to date was initiated and will be completed next month. Descriptions, sizes, temperature and pressure ranges, and materials available are among the tabulation headings being used.

\subsection{Engineering Assistance}

J. M. Holmes

\subsubsection{Contract Objective}

The objective is to provide engineering assistance to the Fossil Energy Major Facilities Project Management Division of ERDA.

\section{4 .2 Status Summiry}

The assistance requested to date on this project has been provided and the total costs are now about equal to the budget. Therefore, no further assignments on this project are expected in FY 1977. 


\subsection{Flash Hydropyrolysis}

S. P. N. Singh

\subsubsection{Contract Objective}

The objectives are to perform a scoping study on two conceptual flash hydropyrolysis processes and to determine if a more detailed engineering evaluation of one of these processes is justified.

\subsubsection{Status Summary}

The draft of the report on the scoping study has been completed and is presently being typed. Preliminary economic analyses are included in the report.

\subsection{Hot Gas Purification Processes \\ M. S. Edwards and J. P. Meyer}

\subsubsection{Contract Objective}

The objective of this project is to investigate the present stateof-the-art hot gas cleanup processes. The application of most interest is the removal of contaminants (i.e., particulates, sulfurous gases, alkali metals, etc.) from coal-derived fuel gas prior to firing combined. cycle turbines.

\subsubsection{Status Summary}

a. Conoco Coal Development Company provided a recent report on their half-calcined dolomite process:

G. P. Curran, B. J. Koch; B. Pasek, M. Pell, and E. Gorin, High Temperature Desulfurization of Low-Btu Gas, Formal Report No: 5, Project No. 550 Series, EPA-600/7-77-031, April, 1977.

b. Various reports on the Battelle Northwest Molten Salt concept.were obtained to provide insight into the process operation and potential.

c. A report on the investigation of possible equipment and methods for use in hot gas purification has been prepared.

\subsection{Large Air Separation Plant Study}

W. R. Reed and W. R. Gambill

\subsubsection{Contract Ob,jective}

The objective of this study is to determine if significant economies of scale would be provided by building single-train cryogenic air 
separation plants with capacities in the range of 2000 to 20,000 TPD oxygen production. The oxygen purity is to be 95 vol.\% or higher; and the delivery pressure, within the range 1 to 70 atm abs., is to be determined by economics.

\subsubsection{Status Summary}

Following the receipt of internal comments, a final subcontract package was prepared; however, ERDA requested that we not proceed with the subcontract.

A summary of the vendor survey and of other relevant activities was completed and will be issued later.

\subsubsection{Changes}

The study was terminated since ERDA/FE/MFPM believes that the more important information will be available sooner from other studies.

\subsection{Review of State-of-the-Art of Processes for Heat Recovery}

W. R. Gambill

\subsubsection{Contract Objective}

The objective of this review is to survey, appraise, and catalog the processes for heat recovery which industry offers or plans to offer or may logically be expected to offer. These processes will be applicable to the recovery of heat in process streams from primary exothermic coal conversion and combustion process steps. Simple unaugmented application of conventional heat transfer equipment will not be included. The review will distinguish between presently installable technology, near term developable technology, and future prospects. Consideration will be given to possible transfer of technology from other industries.

\section{8 .2 Status summary}

a. An inquiry was sent to the Rocketdyne Division of Rockweil International concerning their new industrial thermal storage system which utilizes high-temperature heat transfer fluids flowing through a storage unit containing rock. The stored heat is usable for generation of process steam or electrical power, process heating and drying operations, and space and water heating. A significant cost reduction is claimed.

b. A summary article on the fluid mechanics of heat pipes was located which includes a lucid summary of the several operating limits imposed by fluid dynamics considerations.

c. The Waste Heat Management Guidebook (NBS, Feb. 1977) was received. Chapter 5, titled "Commercial Options in Waste Heat Recovery Equipment," is relevant to this review. Approaches and equipment 
described in a semi-quantitative fashion include gas to gas heat exchangers (recuperators, heat wheels, air preheaters, and heat-pipe exchangers), gas or liquid to liquid regenerators (finned tube, shell and tube, waste heat boilers), gas and vapor expanders, and heat pumps.

\subsection{Assessment of a Moving Bed System for Heat Recovery and Contaminant Removal from Raw Gasifier Gas}

R. W. Glass

\subsubsection{Contract Objective}

The objective is to evaluate the feasibility of a proposed moving bed system for recovery of heat and removal of sulfur and particulates from raw gasifier gas.

\subsubsection{Status Summary}

Basic process calculations were completed for the proposed moving bed filter system.

\subsubsection{Open Items}

The proposed system will be discussed in a meeting at ORNL on August 3. A conventional system for recovering heat, dust, and sulfur will be selected as a basis for evaluation. A design capacity to be used for the evaluation will also be selected.

\subsubsection{Supporting Data}

Sand Circulation. Sand enters the top of the filter and flows down, as a moving bed, between louvered plates set a foot or two apart. The sand enters at a temperature a little above the gas dew point and is heated to about $1550^{\circ} \mathrm{F}$ by direct contact with the gas stream. Iron in the inlet sand is in the completely oxidized state $\left(\mathrm{Fe}_{2} \mathrm{O}_{3}\right)$. In passing through the filter it is reduced at least to $\mathrm{FeO}$ by reaction with reducing agents in the gas stream. $\mathrm{H}_{2} \mathrm{~S}$ in the gas reacts with $\mathrm{Fe} 0$ to 
form FeS and water. Dust, containing ash and carbon, is trapped in the sand where it is held in contact with the hot gas long enough for most of the carbon to be gasified by reaction with water vapor in the gas stream.

Sand leaving the f'ilter f'lows by gravity to the sulfur oxidizer, $R-50$, and then passes through two fluidized sand coolers in series. $\mathrm{R}-20, \mathrm{R}-30$, and $\mathrm{R}-50$ would probably be included in a single vessel; however, they are shown as separate vessels on the flow diagram for clarity and for assigning stream numbers for flow analysis. The beds are fluidized by a gas stream containing oxygen that flows through the three beds in series.

Sand entering the sulfur oxidizer contains FeO, FeS and ash. The iron is oxidized to $\mathrm{Fe}_{2} \mathrm{O}_{3}$ and sulfur is oxidized to $\mathrm{SO}_{2}$. Ash is elutriated from the bed and leaves the vessel with the exit gas stream. The bed is operated at about $1200^{\circ} \mathrm{F}$ with sensible and reaction heat removal by steam generating and superheating tube bundles located in the bed.

Sand containing $\mathrm{Fe}_{3} \mathrm{O}_{3}$ leaves the sulfur oxidizer and flows by gravity through the steam-generating cooler, $\mathrm{H}-30$, which operates at about $600^{\circ} \mathrm{F}$, and the water-cooled cooler, H-20, where the sand is cooled nearly to the dew point of the gasifier gas. The sand is then elevated by a closed-circuit gas lift and enters the top of the filter to complete the cycle. Fines that escape the disengaging vessel are collected in separator $\mathrm{S}-14$ and sent to cooler $\mathrm{H}-30$ where the coarse and fine particles are separated by elutriation.

Gas Circulation. A superficial gas velocity in the order of 2 feet per second will be required for proper fluidization of the sand conolers and sulfur oxidizer. The required amount of gas is circulated by the fluidizing gas circulator, $\mathrm{K}-22$, which is a single-stage centrifugal compressor. Very little reaction between gas and solids takes place in the two sand coolers. In the sulfur oxidizer FeO and Fes react with oxygen contained in the gas stream to form $\mathrm{Fe}_{2} \mathrm{O}_{3}$ and $\mathrm{SO}_{3}$. The $\mathrm{SO}_{3}$, and all of the ash and too-fine sand, leave R-50 along with the exit gas. Heat is recovered from the gas stream in a waste heat boiler, and dust is removed from the relatively cool stream by the fluidizing gas dust separator S-54. The dust is let down to atmospheric pressure by lock hoppers and sent to a disposal area. The gas is returned to the circulator.

Following the dust separator, enough gas is withdrawn in stream 54 to remove the $\mathrm{SO}_{2}$ formed. Oxygen is added by oxygen compressor, $\mathrm{K}-56$, for oxidation of iron and sulfur and to replace oxygen removed in stream 54. If oxygen is not available, air could be used, but the $\mathrm{SO}_{2}$ in stream 54 would be diluted by a relatively large amount of nitrogen. 
Steam Generation. The best arrangement of steam generating tubes in a fluid bed is usually in a manner that is not suitable for natural circulation of boiler water. A forced circulation system is shown on the flow diagram using boiler circulating pump P-42. The pump takes water from the steam drum and circulates it, in parallel, through tube bundles in $\mathrm{H}-30, \mathrm{H}-50$ and $\mathrm{H}-52$. Saturated steum from the steam drum flows through a tube bundle in R-50 where it is superheated to the desired temperature. It appears, on consideration of the heat quantities and temperature levels involved that generation of superheated steam at 600 psia and $850^{\circ} \mathrm{F}$.would be close to the optimum conditions.

7.10 Technical/Economic Assessment of Hydrogen Production by the Steam/Molten Iron Process

R. W. Glass

\subsection{0 .1 Contract Objective}

The objective is to determine if there is sufficient incentive to develop the subject process for production of hydrogen from coal.

\subsection{0 .2 Status Summary}

a. Concurrence with MFPM on the subject work statement and acceptance of the proposed subcontract are pending.

b. Mr. Leonard Seglin is being requested to provide the subcontract effort based on his experience and availability.

7.11 A Study of Effiuent Control Technologies for Hydrocarbon and Carbon Monoxide Emissions

from Coal Conversion Plants - DECT

J. M. Holmes, J. Fisher, and G. Peterson

\subsubsection{Contract Objective}

The objective of this project is to provide a technical and economic comparison of processes available for the control of gaseous hydrocarbon (HC) and carbon monoxide (CO) emissions. The Lurgi gasification process and the HCOAL liquefaction process will be considered as reference source systems, and comparisons of control technologies will consider incineration as the reference control system.

\subsection{1 .2 Status Summary}

Alternates to the decontamination by incineration of the waste gas streams from the Rectisol purification step in a Lurgi SNG plant are being investigated. A representative stream from a 250 MM SCFD Lurgi SNG plant was chosen for the study. The procesees being conoidcred includc: incineration; adsorption on activated carbon; $\mathrm{CO}$ removal by the cuproammonium route; and fuel gas recovery by liquid $\mathrm{CO}_{2}$ scrubbing or hot carbonate removal of $\mathrm{CO}_{2}$. 


\section{PROCESS AND PROGRAM ANALYSIS}

J. R. McWherter

Process and program analysis studies are being conducted for the ERDA Fossil Energy Office of Program Planning and Analysis. This effort includes research studies on most of the coal conversion and utilization processes. The program objective is to provide, on a consistent basis, technical and economic evaluations of competing processes and systems for coal conversion and utilization.

\subsection{Low Btu Coal Gasification}

H. F. Hartman, D. E. Reagan, and J. P. Belk

\subsubsection{Process Screening and Selection}

A draft of the screening and selection section of the low Btu study report was issued for comment. The section contained a description of the factors considered in selecting (a) 54 of the originally considered 85 processes for the process summary section, and (b) 'c'c processes for more detailed comparison and evaluation. All of the processes were listed and the reasons were noted for selecting (or rejecting) certain ones for further consideration. Commercial or advanced development status led to the selection of about half of the processes for the detailed comparison work. The other half of those processes selected represent unique concepts and/or are being t'unded by ERDA.

\subsubsection{Process Data}

Technical data subsections for six processes were prepared for internal review, These six for which data acquisition and assembly are nearly complete are as follows:
Fixed Bed:
(1) Lurgi - dry ash
(2) Lurgi - slagging
Fluidized Bed:
(3) U-GAS (IGT)
(4) Westinghouse
Entrained Flow:
(5) Combustion Engineering
(6) Texaco

Data acquisition and review are continuing for the other gasification processes that will be included in the Process Data Section.

\subsubsection{Process Comparisons}

Work began on the comparisons of low Btu processes. The comparisons will be based on information contained in the Process Data Section. The following characteristics will be summarized for all processes-if data are available. 


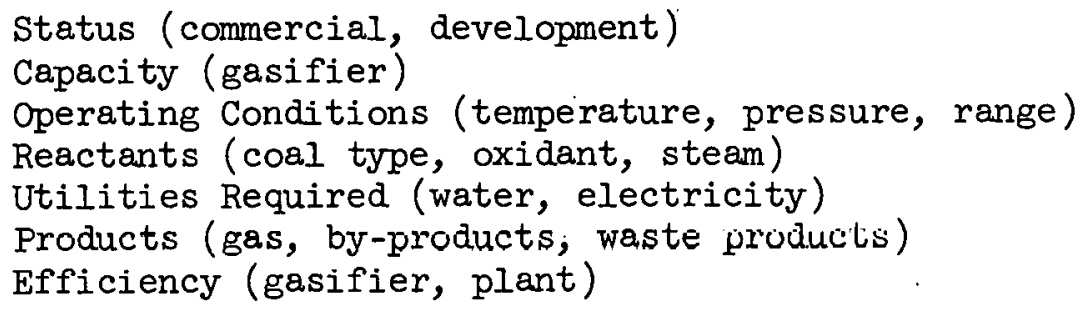

\section{1 .4 Other Activities}

Suggestions and data were provided to coal conversion project personnel regarding (a) the Lurgi - dry ash process, (b) the Lurgi - slagging process, and (c) applications for low Btu processes.

\subsection{Direct Combustion}

E. C. Fox, T. D. Anderson, H. I. Bowers, and J. R. Tallackson

\subsubsection{Objectives}

The purpose of this study program is to assist ERDA/FE in their effort to develop a National strategy to increase the near-term use of coal through direct combustion; the applications of interest in this study are the small-to-moderate industrial user and the large residential/ commercial user. The following objectives will be accomplished:

1. Identify and quantify the important factors restricting the use of coal in the sectors of interest.

2. Evaluate potential technological and institutional solutions to the problems identified in (1) above.

3. Make recommendations to ERDA/FE relative to the most promising approaches to increasing the near-term use of coal.

\subsubsection{Results}

Much of the month was spent evaluating the economic incentives for small industrial and residential/commercial users to convert from natural gas or oil to coal. United Engineers and Constmuctors have provided cost information that is being used as the framework for this analysis. This information has been normalized by $\mathrm{H}$. Bowers to project capital and nonfuel and operating costs as a tunction of plant size. The results are preliminary but indicate that below a size of about $500,000 \mathrm{lb} / \mathrm{hr}$ of steam, coal firing is not competitive with oil at $\$ 14 / \mathrm{bbl}$, assuming $7 \%$ escalation of fuel costs and industrial financing.

Further contact has been made with commercial and small industrial users. T. D. Anderson and E. C. Fox are planning to meet with corporate energy planners of $3-M$ and Sears Roebuck and Co. sometime in August. 
Additionally, further contact has been made with vendors of package coal fired boilers. T. D. Anderson and E. C. Fox met with W. J. Arnold, who is a representative of the E. Keeler Boiler Company. Mr. Arnold provided company cost estimates for package boiler system and agreed to review the results of this study when they are available.

\subsection{Advanced Power Conversion Systems}

A. P. Fraas, * G. Samuels, M. E. Lackey,

W. M. Wells, S. Thompson, and Fred J. Young*

The final three reports, supercritical $\mathrm{CO}_{2}$, conventional steam and the summary report, on Advanced Power Conversion Systems were completed in draft form and forwarded to OPPA-FE during the month. Another report, alkali metal Rankine systems, was revised to conform to the format of the other reports of the series. All twelve reports are being sent to experts in the various systems covered in this series for their review and comments.

\subsection{Liquuefaction}

The Ralph M. Parsons Company is working under subcontract on this subprogram with J. B. O'Hara as Project Manager.

\subsubsection{Survey of Liquefaction Processes}

The preliminary report summarizing the characteristics of 32 liquefaction processes reviewed during the screening survey was drafted. The report. has been sent to the Parsons' publications department for final editing. Copies of reference articles are included with the report.

\subsubsection{Detailed Review of High Potential Liquefaction processes}

Parsons completed a fixed capital investment estimate for a complex to produce 50,000 barrels per day of gasoline by the use of the Mobil M Gasoline process. The grass roots complex includes facilities for:

1. Production of synthesis gas from coal.

2. Conversion of synthesis gas to crude methanol.

3. Production of yasullue by cunversion of crude methanol to gasoline using the Mobil M - Gasoline process.

4. Ancillaries and off-sites to serve the process plants and the total operation of the complex.

\footnotetext{
${ }^{*}$ Consultant
} 
Economic analyses were made of the various components contributing to the gasoline required product selling price. The results show that about $75 \%$ of the product cost was due to the cost of synthesis gas, including the cost of purchased coal. The production of methanol and conversion of methanol to gasoline steps each contributed about equally to the remaining $25 \%$ of the cost.

The preparation of an initial draft of a report describing the results of the Mobil M - Gasoline process review was completed.

\subsubsection{Standard Techniques for Process Evaluation}

The process evaluation techniques are being finalized.

\subsubsection{Uniform Economic Comparison Basis}

The procedure for economic comparison of the leading candidate processes is in progress.

\subsection{High Btu Gas}

This subprogram is being analyzed under subcontract by the Scientific Design Company, Incorporated (SD) with A. S. West as Project Manager.

\subsubsection{Contract Objective}

The objective of the work is to provide technical and economic evaluations of competing processes, concepts, and systems for the production of high Btu gas from coal.

\subsubsection{Status Summary}

Work is continuing on developing a "Generalized Approach to High Btu Coal Gasification." The major process parameters affecting capital, operating and gas costs for methanation, shift and sulfur recovery have been established.

\subsection{In Situ Coal Gasification}

W. C. Ulrich, M. S. Edwards, and R. Salmon

\subsubsection{Contract Objective}

The objective of this program is to provide technical and economic evaluations of candidate processes for the conversion of coal in situ to fluid products presently of interest.

\subsubsection{Status Summary}

a. Capital and operating cost estimates were completed for a 900 MW(e) combined-cycle gencrating plant fueled by low-Btu gas 
produced from a linked vertical well (LVW) coal gasification process. These estimates gave a product price for electricity ranging from about 15 to $40 \mathrm{mills} / \mathrm{kwh}$, depending on cost of coal, type of financing assumed, etc.

b. A substitute natural gas (SNG) plant design, also based on the LVW process, was prepared and is now being cost estimated. The plant was designed to produce 150 MMscf/day of SNG with a higher heating value of $956 \mathrm{Btu} / \mathrm{scf}$ (dry basis). The capital cost of this plant is being estimated by means of the ICARUS COST code, and work is proceeding on the operating cost estimate.

c. Design of a syngas plant for chemical feedstock production was initiated.

\subsubsection{Open Items}

Review by OPPA (and others) of' the draft report, "Evaluation of In Situ Coal Gasification on a Regional Basis," is continuing.

\subsection{Coal Dencficiation}

G. R. Peterson, S. P. N. Singh, and R. Salmon

\subsubsection{Contract Objective}

The objective of this project is to provide technical and economic evaluations of current beneficiation processes.

\subsubsection{Status summary}

The draft report is being revised to reflect comments received in the review with ERDA/OPPA.

\subsection{Gas Cleanup Studies}

M. U. L'dwarde and R. Sulmus

\subsubsection{Contract Objective}

The objective of the gas cleanup study is to collect informat1on on the technology and economics of processes for the remuval of impuritica. (principally hydrogen sulfide) from fuel gas streams. High and low temperature cleanup processes will be reviewed.

\subsubsection{Status Summary}

a. A description of the Benfield Process is being prepared. Following completion of associated drawings, the description will be sent to the process vendor, the Benfield Corporation, for comments. 
b. A process description of the Selexol process (Allied Chemical) is nearing completion. Process economic considerations are being written.

\subsection{Coal Prices and Volumes}

o. L. Culberson*

The draft report is being reviewed and comments are being received.

\subsection{The Potential of the Synthesis of Chemicals from Coal as an ERDA Research Program}

This work is being done under subcontract by the Radian Corporation with D. N. Garner as the Project Director.

The final report on this project is being prepared and is expected to be completed in August.

*Consultant. 
9. FOSSIL ENERGY ENVIRONMENTAL PROJECT

C. R. Boston

\subsection{Landfill Storage of Coal Conversion Solid Wastes/Information Assessment}

H. M. Braunstein

Al1 comments have now been received and finalization of the document is proceeding with delivery to ERWA expected iu September 1977.

\subsection{Landfill Storage of Coal Conversion Solid Wactes/Experimenta]. Phase}

W. J. Boegly

Contacts were made with three gasification pilot plants regarding availability of residue and feed coal samples for laboratory leaching tests. One sample ( $\mathrm{CO}_{2}$ Acceptor) was recelved during July. Two others - Hygas and Waltz Mills - agreed to send samples to ORNL. Hygas waste will be in slurry form. Approximately $3 \mathrm{ft}^{3}$ of residue and feed coal have been requested. Laboratory leaching tests will be initiated next month and preliminary design of field size lysimeters will be started. Project is approximately on schedule; however, staffing problems and unavallability of wastes may slow down progress to some degree. A trip to the Hygas pilot plant (IGT) has been planned for late August.

\subsection{Environmental Monitoring Handbook}

L. H. Stinton .

Revision 2 of the Environmental Monitoring Handbook was submitted to ERDA on July 29, 1977, which was the delivery date projected in the June progress report. Section IV.1.5 on atmospheric monitoring during plant operation was not included in this draft but w1ll be submitted as an addendum. This revision includes all four parts of the Handbook, i.e., Introduction, Preconstruction, Construction, and Uperation. Comments have been solicited for receipt by September 15, 1977. 


\subsection{Programmatic Assessment/Pipeline Gas}

L. H. Stinton

The first draft of the Programmatic Environmental Assessment for Pipeline Gas Demonstration Plants was submitted to ERDA on July 15, 1977, five days earlier than was projected in the June progress report. Comments are to be returned by August 15, 1977, for document finalization by September 15, 1977.

\subsection{Programmatic Assessment/Fuel Gas}

L. H. Stinton

An intensive effort on the Programmatic Environmental Assessment for Fuel Gas Demonstration Plants was initiated this month and four sites were selected. These sites were Baskett, Kentucky; Memphis, Tennessee;

New Orleans, Loulsiana; and Tulsa, Oklahoma. A document outline was prepared and 1iterature on these four sites is being acquired. Due to the ERDA requested delay in starting this document (i.e., July 1 instead of April 1), it is anticipated that the draft document w111 not be available until November 15 (as opposed to September 15). 
INTERNAL DISTRIBUTION

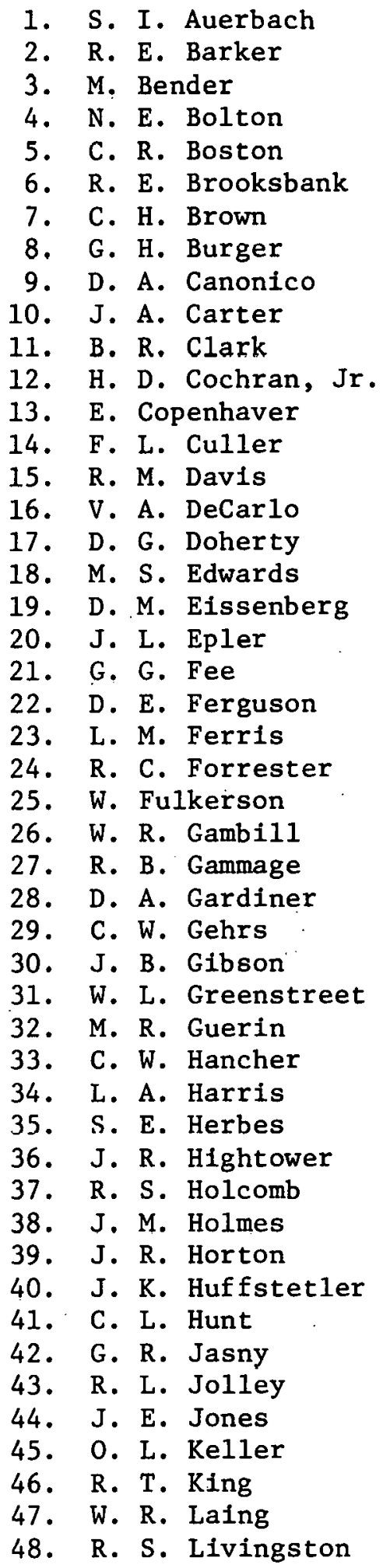

49. R. E. MacPherson

50. A. P. Malinauskas

51. G. B. Marrow

52. C. J. McHargue

53. L. E. McNeese

54. J. R. McWherter

55. H. J. Metz

56-58. W. R. Mixon

59. J. E. Mrochek

60. P. Nettesheim

61-65. J. P. Nichols

66. L. C. Oakes

67. G. E. Oswald

68. G. R. Peterson

69-70. T. W. Pickel

71. W. W. Pitt

72. H. Postma

73. D. E. Reichle

74. C. R. Richmond

75. B. R. Rodgers

76. M. W. Rosentha1

77. R. H. Ross

78. T. H. Row

79. W. L. Russel1

80. R. Salmon

81. G. Samuels

82. C. D. Scott

83. D. S. Shriner

84. W. D. Shults

85. S. P. N. Singh

86. C. B. Smith

87. G. P. Smith

88. I. Spiewak

89. R. L. Spore

90. E. G. St. Clair

91. J. B. Storer

92. R. A. Streh1ow

93. O. K. Tallent

94. A. J. Thompson

95. D. B. Trauger

96. W. C. Ulrich

97. P. R. Vanstrum

98. J. S. Watson

99. J. R. Weir

100. P. R. Westmoreland

101. M. K. Wilkinson

102. L. V. Wilson

103. R. G. Wymer 
104. C. S. Yust

105. Patent office

106. Lab. Records
107-113. Lab. Records

114-116. Central Research Library

117. Document Reference Section

\section{EXTERNAL DISTRIBUTION}

ERDA, Oak Ridge Operations

118. Research and Technical Support Division

ERDA, San Francisco Operations

119. N. S. Hagen

ERDA, Washington

120. W. Bakker, MER

121. N. F. Barr, DTO

141. T. K. Lau, MFPM

122. J. D. Batchelor, CCU

142. R. W. A. LeGassie, APA

123. R. Beck, CCU

143. J. L. LIverman, AES

124. T. Beresovski, RIJD

125. L. M. Burman, OGST

144. W. G. McDante1, MFPM

126. E. L. Clark, CCU

145-150. C. Millier, CCU

151. G. A. Mills, MER

127. N. P. Cochran, MFPM

152. W. E. Mott, DBER

128. T. Cox, MER

129. P. Duhame1, MER

130. J. Forst, MER

131. H. Franke1, MER

132. S. I. Freedman, CCU

133. D. Garrett, MFPM

134. S. W. Gouse, AFE

135. W. S. Harmon, MFPM

1.53. M. B. Nelworth, CCII

154. E. S. Pierce, DPR

155. H. E. Poda11, MFPM

156. J. L. Powell, MFPM

157. J. W. Ramsey, OGST

158. M. Reilly, FE/OPPA

159. John Shen, MER

160. A. P. Sikri, OGST

161. D. K. Stevens, DPR

136. K. M. Jimeson, DTO

162. J. W. Watkins, OGST

137. H. R. Johnson, FE/OPPA

163. P. C. White, AFE

138. H. Jones, MFPM

139. L. Kindley, MER

164. P. R. Wieber, OGST

140. C. Knudsen, FE/OPPA

165. R. W. Wood, DBER

Department of Housing and Urban Development, 451 th Street, S.W., Washington, DC 20410

166. ก. S. Leigliton

167. J. H. Rothenberg

National Science Foundation, 1800 G Street, N.W., Washington, DC 20550

168. R. S. Goor

169. Robert Rabin

University of Kentucky, Institute for Mining and Materials Research,

213 Bradley Hall, Lexington, KY 40506

170. Theresa Wiley, Institute Librarian

1/1. 0. J. Haun

172. J. K. Shau 
173. Charles B. Sedman, U.S. Environmental Protection Agency, Research Triangle Park, NC 27711

174._-N._S._-Boodman, Section Supervi-sor, U.S -- Steel Corporation Applied -... Research Laboratory, 125 Jamison Lane, Monroeville, PA 15146

175-186. ERDA Pittsburgh Energy Research Center, U.S. Energy Research and Development Administration, Attention: Director for J. P. Barreca, 4800 Forbes Ave., Pittsburgh, PA 15213

187-192. The Director, Morgantown Energy Research Center, P.0. Box 800, Morgantown, WV 26506

193. Tetra Tech, Inc., 1911 N. Ft. Myer Drive, Sulte 601, Arlington, VA 22209, Attention: Walter McGough, Jr.

194. Cameron Engineers, Attn: Gary L. Baughman, 1315 South Clarkson St., Denver, CO 80213

195. Y. A. Liu, Department of Chemical Engineering, Auburn University, Auburn, Alabama 36830

196. W. E. Warnke, Coal Preparation Research Manager, U.S. Bureau of Mines, 2401 E Street N.W., Washington, DC 20241

197-223. Technical Information Center, ERDA 